\title{
Recent advances in postharvest technologies to extend the shelf life of blueberries (Vaccinium sp.), raspberries (Rubus idaeus L.) and blackberries (Rubus sp.)
}

\author{
Nha K. Huynh ${ }^{\mathrm{a}, *}$, Matthew D. Wilson ${ }^{\mathrm{a}}$, Alieta Eyles ${ }^{\mathrm{a}}$ and Roger A. Stanley ${ }^{\mathrm{a}, \mathrm{b}}$ \\ ${ }^{\mathrm{a}}$ ARC Training Centre for Innovative Horticultural Products, Tasmanian Institute of Agriculture, \\ University of Tasmania, Launceston, Australia \\ ${ }^{\mathrm{b}}$ Centre for Food Innovation, University of Tasmania, Launceston, Australia
}

Received 11 April 2019; accepted 16 August 2019

\begin{abstract}
Fresh blueberries, raspberries and blackberries are gaining popularity for their pleasant flavour and health benefits. However, their fresh supply, and the potential for market growth, are still limited by their short shelf life and seasonality. High respiration rates, delicate structures and high susceptibility to fungal decay are the main factors limiting the storability of these berry types. Current industrial practice for a longer shelf life relies heavily on cold chain and high humidity storage conditions. This typically results in a shelf life of 2-4 weeks for blueberries, and 2-5 days for raspberries and blackberries. This review discusses novel postharvest technologies from physico-chemical treatments (heat treatments, UV and edible coatings) to packaging-based solutions to improve the preservation of the freshness of blueberries, raspberries and blackberries through the supply chain. Sanitisation plays a crucial role in preventing fungal growth, while innovative packaging solutions act as complementary treatments to maintain quality attributes. The development and application of such technology combinations will increase berry shelf life, helping to satisfy the increasing global demand for these fresh berry products and improve consumer satisfaction.
\end{abstract}

Keywords: Sanitisation, heat treatment, edible coating, modified atmosphere packaging

\section{Introduction}

Berries are high-value crops that are not only seasonal but also highly perishable [1, 2]. Therefore, increasing their shelf life to enhance distribution options, and to extend availability outside of peak production periods has proven to be challenging $[3,4]$. To date, the berry industry has predominantly relied on cold chain management $\left(0-2^{\circ} \mathrm{C}\right)$ and high humidity $(90-98 \%)$ for maintaining quality [5]. However, recent advances in technology, and the improved understanding of post-harvest berry physiology, could provide opportunities for improving the storability of berries.

\footnotetext{
${ }^{*}$ Corresponding author: Nha K. Huynh, ARC Training Centre for Innovative Horticultural Products, Tasmanian Institute of Agriculture, University of Tasmania, Launceston, Australia. E-mail: KyNha.Huynh@utas.edu.au.
} 
The potential benefits of novel postharvest preservation techniques have been largely focused on strawberries [6-8], with fewer studies published for other commercialised higher value, but smaller production volume, berries including blueberries, raspberries and blackberries $[5,9,10]$. This review aims to firstly summarise the current knowledge of the main factors that influence the shelf life of blueberries, raspberries and blackberries (Section 1) then evaluate a range of postharvest technologies that have been reported to extend the storability of these berries with focus on physico-chemical methods (e.g. heat, UV, sanitisation and edible coatings) (Section 2) and packaging-based solutions (Section 3). Additional technologies that have shown promise for shelf life extension of blueberries and raspberries are described in Section 4.

\subsection{Causes of berry deterioration}

Shelf life could be defined as the potential storage period of a product until it becomes unsuitable for human consumption or is rejected by customers [11]. Shelf life of fresh produce, therefore, is dynamic, depending on (i) the nature of the produce, (ii) preharvest and postharvest environmental conditions, and (iii) consumer expectation. The latter two factors lead to many variations in the definitions and assessments of shelf life of berries between studies. By their nature, shelf life of berries can vary considerably among cultivars, but in general, is still limited due to their high respiration rates $\left(52-245 \mathrm{mg} \mathrm{CO}_{2} \mathrm{~kg}^{-1} \mathrm{~h}^{-1}\right.$ at $20^{\circ} \mathrm{C}$ ), fragile structures and high susceptibility to fungal decay [1,12-14]. The shelf life of raspberries and blackberries can be as short as $2-5$ days, even under optimum storage conditions $\left(-0.5-0^{\circ} \mathrm{C}, 90-95 \% \mathrm{RH}\right)[12,14]$, but some blackberry cultivars such as 'Navaho' and 'Shawnee' were reported to last up to 21 days at $2^{\circ} \mathrm{C}$ [15]. The major species of blueberries grown commercially are highbush blueberry (Vaccinium corymbosum L.), rabbiteye blueberry (Vaccinium ashei Reade/Vaccinium virgatum Ait) and lowbush blueberry (Vaccinium angustifolium Ait) [16]. Depending on chilling requirements and winter hardiness, highbush cultivars are further classified as northern $\left(800-1000 \mathrm{~h}\right.$ of chilling and adapting to cold mid-winter temperatures $\left.<-20^{\circ} \mathrm{C}\right)$, southern $(<550 \mathrm{~h}$ of chilling and not tolerating $<0^{\circ} \mathrm{C}$ ) and intermediate ( $400-800 \mathrm{~h}$ of chilling). Under current best commercial practice conditions $\left(-0.5-0{ }^{\circ} \mathrm{C}\right.$, above $\left.90 \% \mathrm{RH}, 10 \% \mathrm{CO}_{2}\right)$, northern highbush blueberries can last to 2 months, especially if the initial quality is high $[4,17]$. In general, however, the shelf life is typically up to 2 weeks for lowbush, northern highbush and southern highbush cultivars $[18,19]$ and up to 4 weeks for rabbiteye cultivars [20]. The relatively longer shelf life of blueberries has been attributed to the presence of a protective layer of epicuticular wax comprising triterpenoids and $\beta$-diketone [21] that forms a natural barrier against moisture loss and pathogenic attacks [22].

\subsection{Common symptoms of quality deterioration}

\subsubsection{Fungal decay}

Mechanical damages can occur at any stage along the supply chain from the field to the packhouse or during the distribution and retail steps. It can markedly increase the susceptibility of berries to postharvest fungal infection resulting in decay. A visible decay incidence of $1-2 \%$ is considered enough to reduce the marketability of blueberries, raspberries and blackberries $[23,24]$. For blueberries, the most common pathogens causing spoilage are Botrytis cinerea, Alternaria alternata and Alternaria tenuissim (Alternaria rot), and Colletotrichum gloeosporioides (anthracnose fruit rot) [25], while for raspberries and blackberries, they are $B$. cinerea, Cladosporium sp., Fusarium sp., Penicillium sp. and Rhizopus sp. [26]. As discussed below, management of fungal disease is hindered by a current lack of practical sanitisation treatments [27].

\subsubsection{Changes in sensorial attributes}

Sensorial indicators of the shelf life of berries include colour changes, dehydration and softening. Blueberries become darker with storage, turning from bright purplish blue to dark blue due to the loss of the waxy bloom [28], although the amounts of wax may vary with cultivars [21]. Raspberries darken quickly, turning from pink/light red to dark red after harvest, due to an increase in the anthocyanin content and the $\mathrm{pH}$ [29]. Picking raspberries at 
early maturity, i.e. pink and firm, was suggested to improve storability [29] but this may compromise the eating quality [30]. In contrast, blackberries should only be picked when fully black. Mottled blackberries (50\% black) failed to darken even after 7 days at $2{ }^{\circ} \mathrm{C}$ [31]. In addition, blackberries affected by red drupelet reversion disorder revert to red after suffering physical stresses [32].

Postharvest loss of moisture alters fruit appearance, texture and flavour, and reduces marketable weight [33]. Raspberries and blackberries are more prone than blueberries to dehydration due to the lack of epicuticular wax, with a maximum acceptable moisture loss of $6 \%$ [27]. In blueberries, moisture loss of $>2-8 \%$ (depending on the cultivars) reduces the waxy bloom [33], causes loss of firmness and leads to shrivelling [34].

Softening also occurs in all berries owing to the solubilisation and depolymerisation of cell wall compounds due to enzymatic activities [35, 36]. An increase in water-soluble pectin and a decrease in sodium-carbonatesoluble pectin, hemicellulose and cellulose were observed during the softening of blueberry [35]. In raspberries, their quick postharvest softening was correlated to the activities of polygalacturonase and pectin methylesterase [37]. Meanwhile, softening of blackberries was caused by the solubilisation of cell wall pectins, rather than depolymerisation, as evidenced by a 50\% increase of water-soluble uronic acids found during ripening [38].

\subsection{Ethylene effects}

Raspberries are non-climacteric [37], while the climacteric response of blackberries and blueberries varies depending on cultivars [16,39], but all of them are low-ethylene producers $\left(0.1-1.0 \mu \mathrm{L} \mathrm{kg}^{-1} \mathrm{~h}^{-1}\right)$ [40]. Raspberries are highly sensitive to ethylene at pre-harvest [37], but the role of this plant hormone on postharvest quality and storability of raspberries, as well as of blackberries and blueberries, is still not well understood. In raspberries, ethylene increased the incidence of grey mould (B. cinerea) and darkened fruit colour from red to purple-red [41]. However, a recent study of five primocane raspberry genotypes ('BP1', 'Crimson Treasure', 'Heritage', 'Nantahala', and NY 10-24 - a breeding selection from the Cornell raspberry breeding program) found no correlation between ethylene production rates and fruit colour stability or anthocyanin content or shelf life [42]. Blackberry cultivars with higher ethylene production rates were linked with a shorter shelf life [43]. In blueberries, inhibition of ethylene action by its antagonist, 1-methylcyclopropene (1-MCP), had no effects on shelf life and quality of highbush cultivars [44], but accelerated loss of firmness in rabbiteye cultivars [45].

Other plant hormones that contribute to fruit ripening are abscisic acid (ABA) and auxins, but little has been done on their effects, particularly for blueberries, raspberries and blackberries. The activities of these phytohormones on a broader category of soft fruits have been reviewed [10].

\section{Physico-chemical methods for shelf life extension of berries}

\subsection{Heat treatments}

Heat treatments improve the shelf life of fresh produce by reducing physiological changes, eliminating insects of phytosanitary concern and controlling microorganisms and decay on produce surface [46]. While there has been no study applying heat treatments to raspberries and blackberries, possibly because of their delicate structures, beneficial effects were observed in blueberry treated by vapour heat and hot air $\left(>30^{\circ} \mathrm{C}, \mathrm{RH}>90 \%\right)$ [47], and hot water $\left(>40^{\circ} \mathrm{C}\right)$ dipping [48]. For example, incubation at $50^{\circ} \mathrm{C}$ for $30 \mathrm{~min}$ during storage reduced the respiration rate, malondialdehyde content and decay of southern highbush blueberries ('Misty', 'O'Neal' and 'Sharpblue') [47]. Similarly, dipping 'Burlington' blueberries in hot water $\left(45-60^{\circ} \mathrm{C}\right)$ for $15-30$ s lowered weight loss, shrivelling, fruit split, and decay caused by $B$. cinerea and Collectotrichum spp. after 4 weeks at $0^{\circ} \mathrm{C}$ and 2 days at $20^{\circ} \mathrm{C}$ [48]. However, the same study showed that the heat-treated fruits exhibited lower titratable acidity and total soluble solid contents and thinner wax bloom. Heat treatment might also trigger the production of stress-induced volatiles such as ethanol and ethyl acetate [48]. Such responses indicated that the benefits of heat 
treatment in blueberries would particularly require further optimisation of time-temperature combinations, as effective heat treatments are often near to the limits that the fruit can tolerate [49].

\subsection{Ultraviolet $(U V)$ irradiation}

UV radiation refers to a broad band of wavelengths comprised of short-wave UV-C (200-280 nm), mediumwave UV-B (280-320 nm), and long-wave UV-A (320-400 nm). Although all wavelengths have microbicidal effects, UV-A is considered to have little practical value to shelf life extension of fresh produce because of the low absorption by living cells, while UV-C has stronger biocidal effects than UV-A and B, due to its high-energy state [50].

\subsection{1. $U V$-C (short-wave)}

Several studies have shown reductions in microbial load and improvements in produce shelf life treated with UV-C $\left(1-8 \mathrm{~kJ} \mathrm{~m}^{-2}\right)$. UV-C can alter microbial DNA or stimulate the production of photoproducts that suppress the germination of microbial spores [50,51]. However, most of these studies examined blueberries whilst only one study was found for raspberries, and to the best of our knowledge, no studies were performed to date on blackberries. In blueberries inoculated with Escherichia coli O157:H7, 1 - 10 min irradiation using UV-C at $200 \mathrm{~J} \mathrm{~m}^{-2} \mathrm{~s}^{-1}$ reduced the microbial counts on the calyx by $1.5-2.1 \log \mathrm{CFU} \mathrm{g} \mathrm{g}^{-1}$ and on the skin by $3.1-5.5$ $\log \mathrm{CFU} \mathrm{g} \mathrm{g}^{-1}$ [52]. Irradiation with UV-C at $1-4 \mathrm{~kJ} \mathrm{~m}^{-2}$ reduced ripe rot incidence caused by C. acutatum by $10 \%$ after storage for 7 days at $5^{\circ} \mathrm{C}$ followed by 2 days at $20^{\circ} \mathrm{C}$ in northern highbush 'Bluecrop' and 'Collins' cultivars [53]. Although showing some promise for blueberries, caution is required as higher doses $\left(8 \mathrm{~kJ} \mathrm{~m}^{-2}\right)$ of UV-C have been reported to increase decay incidence [53].

The effectiveness of UV-C in inactivating microorganisms has shown to be affected by the physical structure of the produce and the targeted microorganisms. The inactivation kinetics and $\mathrm{E}_{90}$ (the amount of energy required to kill $90 \%$ of the target microorganisms) of UV-C was influenced by surface roughness and spreading coefficients of the commodity being treated [54]. In that study, a 12-min treatment of UV-C at $10.5 \mathrm{~kJ} \mathrm{~m}^{-2}$ only reduced E. coli $\mathrm{O} 157: \mathrm{H} 7$ by $1.1 \log \mathrm{CFU} \mathrm{g}{ }^{-1}$ on inoculated raspberry. In addition, UV-C irradiation, although effective on bacteria, might not be effective against internal rot fungi due to its low penetration depth [55].

Reduced softening by UV-C was observed in boysenberries (Rubus ursinus $\times$ Rubus idaeus), primarily by disrupting cell-wall degrading enzymes [56], but there has been no study showing if the same effects could be achieved for raspberries and blackberries.

Additionally, the stress from the exposure to irradiation may induce the production of antioxidant compounds as part of the fruits' natural defence mechanism [57]. At $2-4 \mathrm{~kJ} \mathrm{~m}^{-2}$, UV-C increased anthocyanins by $10 \%$ in 'Bluecrop' blueberries [53] and increased flavonoids by $10 \%$ in 'Duke' [57, 58], but not in 'Collins' cultivar [53]. Notably, the levels of antioxidants were particularly high immediately after the radiation treatment, but dropped sharply during storage $[57,58]$.

\subsection{2. $U V-B$ (medium-wave)}

UV-B is of interest as an alternative to UV-C because it offers comparable efficacy while being less harmful to overall fruit quality [59]. However, this option might have limited commercial applications on berries. Although irradiation with UV-B at $6 \mathrm{~kJ} \mathrm{~m}^{-2}$ reduced weight loss, decay and delayed increase in the soluble solid - to titratable acidity ratio in 'Duke' blueberries during 28 days of cold storage [58], observed changes in volatiles and phenolics in 'Bluecrop' blueberries irradiated by UV-B at different radiation intensities and durations could imply changes in sensory characteristics [59]. In 'Navaho' thornless blackberries, a daily 3-hour exposure to UV-B radiation (treatment not specified) significantly reduced fungal decay to $10 \%$ after 3 weeks and $40 \%$ after 4 weeks, compared to the control (47\% after 3 weeks and 93\% after 4 weeks) [60], but had adverse effects on fruit appearance when stored for more than 2 weeks. 


\subsubsection{Pulsed UV-light}

Pulsed UV-light refers to the release of intense broad-spectrum electromagnetic radiation (100-1100 nm) energy in short bursts, which may allow greater decontamination potential than conventional UV-light radiation [20, 61]. In inoculated blueberries, treatment with $226 \mathrm{~kJ} \mathrm{~m}^{-2}$ reduced E. coli O157:H7 and Salmonella by 2.9 and $4.3 \log \mathrm{CFU} \mathrm{g} \mathrm{g}^{-1}$, respectively [62]. In inoculated raspberries, pulsed UV-light at $720 \mathrm{~kJ} \mathrm{~m}^{-2}$ reduced $E$. coli O157:H7 by $3.9 \log \mathrm{CFU} \mathrm{g}{ }^{-1}$, and reduced Salmonella by $3.4 \log \mathrm{CFU} \mathrm{g} \mathrm{g}^{-1}$ at $594 \mathrm{~kJ} \mathrm{~m}^{-2}$ [63]. Although pulsed UV-light affords good microbial control, its commercial viability may be discouraged by its effects on fruit sensory properties. High surface temperature due to the heat generated during treatments adversely affected blueberry appearance, including serious discolouration and loss of wax bloom [64]. A system voltage of $3800 \mathrm{~kg}$ $\mathrm{m}^{2} \mathrm{~s}^{-3} \mathrm{~A}^{-1}$ was noted for causing a cooked appearance and loss of integrity in blueberries [62]. Severe darkening and softening over 10 days of refrigerated storage was reported on raspberries treated at $282 \mathrm{~kJ} \mathrm{~m}^{-2}$ for $30 \mathrm{~s}$ [65].

A water-assisted pulsed UV-light system (wet pulsed light) immersing the produce in agitated water was proposed to minimise the temperature increase and allow fruit movement and rotation for better energy distribution [64]. Indeed, $60 \mathrm{~s}$ of water-assisted pulsed light reduced E. coli O157:H7 and a 4-strain cocktail of Salmonella by $>5.8 \log \mathrm{CFU} \mathrm{g}^{-1}$ in inoculated blueberries while fruit appearance remained unchanged [64]. Similarly, the same treatment reduced Salmonella by $3 \log _{\mathrm{CFU} \mathrm{g}}{ }^{-1}$ in inoculated raspberries [66]. The feasibility of this technology, however, could be limited by the residual surface moisture left on berries, which can encourage microbial growth [27].

\subsection{Sanitisation}

In general, sanitisation by washing is not recommended for berries as it can promote mechanical damage and residual surface moisture, particularly in raspberries owing to their hollow structure [27]. The few studies that have reported the efficacy of sanitisers mostly examined blueberries with a focus on food safety rather than fruit quality and control of fungal decay. Washing with $50-100 \mathrm{mg} \mathrm{L}^{-1}$ chlorinated water failed to reduce microbial load in blueberries [67]. In contrast, sulphur dioxide $\left(\mathrm{SO}_{2}\right)$ fumigation reduced fungal decay incidence of eight blueberry cultivars ('Emerald', 'Jewel', 'Legacy', 'Misty', 'Reveille', 'Snow', 'South Moon', and 'Star') over 28 and 35 days of cold storage at $1^{\circ} \mathrm{C}$ [68], and for six cultivars ('Brigitta', 'O'Neal', 'Duke', 'Legacy', 'Elliott', and 'Aurora') over 45 days at $0-1{ }^{\circ} \mathrm{C}$ followed by 3 days at $20^{\circ} \mathrm{C}$ [69]. This was achieved without altering fruit quality even at an applied gas level as high as $194 \mathrm{~nL} \mathrm{~L}^{-1} \mathrm{~s}^{-1}$ [68]. The $\mathrm{SO}_{2}$-treated blueberries also had less decay when stored in ambient atmosphere compared to the untreated fruits stored in controlled atmosphere (3\% $\mathrm{O}_{2}, 3-12 \% \mathrm{CO}_{2}$ ). A major obstacle of sulphite use is the consumer opposition to additives [70] and possible allergic reactions, particularly for asthmatics [71]. The use of $\mathrm{SO}_{2} /$ sulphite must be declared on package labelling. Consumer concerns around possible health effects of sodium hypochlorite and sulphur dioxide have encouraged researchers to look for alternatives, with chlorine dioxide $\left(\mathrm{ClO}_{2}\right)$ and ozone being the most studied for berries.

\subsubsection{Chlorine dioxide $\left(\mathrm{ClO}_{2}\right)$}

$\mathrm{ClO}_{2}$ is a powerful oxidiser, 2.5 times stronger than chlorine in oxidation capacity and is capable of penetrating microbial cell walls and altering cellular metabolism [72]. $\mathrm{ClO}_{2}$ can be used as an antimicrobial agent in both gaseous and aqueous forms. Aqueous $\mathrm{ClO}_{2}$ is stable at $\mathrm{pH}$ 6.0-10.0 [72], but less effective than its gaseous state which provides better penetration into small areas where water cannot penetrate due to surface tension [73]. In the USA, the highest level of aqueous $\mathrm{ClO}_{2}$ allowed for whole fresh produce is $3 \mathrm{mg} \mathrm{L}^{-1}$ and the treated produce must be subsequently washed with clean water [74].

Dipping blueberries in aqueous $\mathrm{ClO}_{2}\left(2 \mathrm{mg} \mathrm{L}^{-1}, 2 \mathrm{~min}\right)$ maintained fruit firmness and resulted in significant but small reductions of decay incidence after an 8-day storage at $4 \pm 1{ }^{\circ} \mathrm{C}(19 \%$ decay, vs. $22 \%$ in the untreated $)$ [75]. Similarly, treatment with 1 and $3 \mathrm{mg} \mathrm{L}^{-1}$ for $10 \mathrm{~s}$ to $1 \mathrm{~h}$ reduced five foodborne pathogens (Listeria monocytogenes, Pseudomonas aeruginosa, Salmonella sp., Staphylococcus aureus and Yersinia enterocolitica), yeasts and moulds in inoculated blueberries by $<2 \log \mathrm{CFU} \mathrm{g}{ }^{-1}$ [76]. The effectiveness of aqueous $\mathrm{ClO}_{2}$ increased 
when higher concentrations and/or longer treatment times were applied. For example, increasing to $15 \mathrm{mg} \mathrm{L}^{-1}$ of $\mathrm{ClO}_{2}$ for $1 \mathrm{~h}$ reduced microbial load by up to 2.43-4.25 $\log \mathrm{CFU} \mathrm{g}{ }^{-1}$ [76]. Likewise, dipping blueberries at a much higher concentration of $\mathrm{ClO}_{2}\left(100 \mathrm{mg} \mathrm{L}^{-1}\right)$ for $10 \mathrm{~min}$ with agitation resulted in nearly $1-1.5 \log \mathrm{CFU}$ $\mathrm{g}^{-1}$ less total aerobic bacteria and fungi counts than wash water, without affecting sensory quality and overall acceptability over 12 days of storage at 4 and $20^{\circ} \mathrm{C}$ [77].

Gaseous $\mathrm{ClO}_{2}\left(4.1 \mathrm{mg} \mathrm{L}^{-1}, 30 \mathrm{~min}\right.$ at $23^{\circ} \mathrm{C}$ and $\left.75-83 \% \mathrm{RH}\right)$ reduced $S$. enterica and fungi by $0.52 \log \mathrm{CFU}$ $\mathrm{g}^{-1}$ and $3.02 \log$ CFU g ${ }^{-1}$, respectively, in inoculated raspberries, and by up to $2.70 \log \mathrm{CFU} \mathrm{g}^{-1}$ in blueberries [78]. Increasing treatment times to 60 and $120 \mathrm{~min}$, and $\mathrm{ClO}_{2}$ concentrations to 6.2 and $8.0 \mathrm{mg} \mathrm{L}^{-1}$, however, provided no additional benefits. Treatment with $\mathrm{ClO}_{2}$ gas at $4 \mathrm{mg} \mathrm{L}^{-1}$, but over a longer duration i.e. $12 \mathrm{~h}$ was also effective in reducing microbial growth of blueberries inoculated with Listeria monocytogenes, Salmonella, E. coli O:157:H7 as well as yeasts and moulds [67]. Sensorial attributes were unaltered in both studies [67, 78]. $\mathrm{ClO}_{2}$ gas released from pads embedded in packaging was found to lower yeasts and mould counts of raspberries as well as reduce fruit weight loss and improve fruit redness intensity compared to the control after 8 days at $1^{\circ} \mathrm{C}[79]$.

\subsubsection{Ozone}

Ozone is a strong oxidising agent that has shown potential as a sanitiser for blueberries [80, 81], raspberries [82] and blackberries [83, 84]. It is typically applied in gaseous form. The ozone decomposes to $\mathrm{O}_{2}$ and is recognised as GRAS (Generally Regarded as Safe) by the US Food and Drug Administration [85].

Treatment of blueberries with $700 \mu \mathrm{L} \mathrm{L}^{-1}$ ozone for 2 or 4 days prior to controlled atmosphere storage (15\% $\mathrm{O}_{2}, 10 \% \mathrm{CO}_{2}$ ) increased marketable yield by $4 \%$ and $7 \%$, respectively, compared to the control [81]. Ozone storage also maintained firmness of 'Ozark Blue' blueberries after 10 days [86] and 'Brigitta' blueberries after 5 weeks, although this effect was not consistent across the three cultivars ('Bluecrop', 'Coville' and 'Brigitta') [80]. In 'Chester' blackberries, no fungal decay was observed following continuous exposure to ozone for 12 days at $0.1-0.3 \mu \mathrm{L} \mathrm{L}^{-1}$, compared to $20 \%$ for the untreated fruits [83]. In contrast, ozone storage $\left(4 \mu \mathrm{L} \mathrm{L}^{-1}\right.$ at $4^{\circ} \mathrm{C}$ and $2.5 \mu \mathrm{L} \mathrm{L}^{-1}$ at $12^{\circ} \mathrm{C}$ ) was unable to control natural yeasts and moulds in 'Ozark Blue' blueberries over 10 days [86].

A further benefit of ozone is its ability to oxidise ethylene, thereby delaying ripening and senescence in ethylene-sensitive fruits including berries [87]. However, exposure to ozone can trigger a stress response altering the fruit metabolism. Respiration rates of 'Coville' blueberries increased immediately after 1-2 day(s) of constant treatments of $200 \mu \mathrm{L} \mathrm{L}^{-1}$ ozone [81]. In addition, the concentration of stress-indicating compounds such as methanol, ethanol and 2-nonanone (methyl heptyl ketone) increased markedly in 'Coville' blueberries stored in $700 \mu \mathrm{L} \mathrm{L}^{-1}$ ozone for $2-4$ days, suggesting changes in flavours. Similarly, 'Grandeur' raspberries had better overall sensory quality than the control when stored for 9 and 15 days under continuous ozone flushing at either of $500 \mu \mathrm{L} \mathrm{L}^{-1}$ or a combination of $12 \mathrm{~h}$ of $200 \mu \mathrm{L} \mathrm{L}^{-1}+12 \mathrm{~h}$ of $50 \mu \mathrm{L} \mathrm{L}^{-1}$. However, the higher concentrations resulted in lower scores for taste and flavours [82].

Industrial applications of gaseous ozone have been hindered by the risk of explosion and toxicity to the operators [88]. Alternatively, ozonated water, which is generated by passing ozone through water, could be a solution although residual moisture may restrict the practical feasibility of this option for berries. Ozonated water $\left(0.6 \mathrm{mg} \mathrm{L}^{-1}\right.$ for $\left.3 \mathrm{~min}\right)$ was as effective as chlorine $\left(200 \mathrm{mg} \mathrm{L}^{-1}\right)$ in reducing yeast and moulds $(0.6$ and 0.87 $\log$ CFU g ${ }^{-1}$, respectively) in 'Tupi' blackberries without affecting the fruit colour, total phenolic content or antioxidant activity [84].

\subsection{Edible coatings}

Edible coatings are thin layers of edible biomaterials that can maintain fruit freshness and increase shelf life by acting as protective barriers preventing moisture loss and microbial growth, as well as limiting $\mathrm{O}_{2}$ and $\mathrm{CO}_{2}$ 
exchange (Table 1). However, the use of coatings can be incompatible with extension of shelf life and accelerate ripening resulting in higher productions of $\mathrm{CO}_{2}$, ethylene and fermentation-related volatiles as observed in blackberries coated with cassava starch and kefir [89] and starch-beeswax [90].

Findings from the literature indicate that chitosan-based edible coatings may be most promising at improving the shelf life of blueberries, raspberries and blackberries (Table 1). Chitosan (poly $\beta-(1-4)-\mathrm{N}$-acetyl-Dglucosamine) is a polysaccharide derived from chitins that has been extensively studied to extend the shelf life of fresh produce [91]. In the context of berries, fruit weights were maintained, and large reductions of fungal decay were observed in various blueberry cultivars (5-30\%) [92-95], 'Tupy' blackberries (45\%) [96] and 'Tullmeen' raspberries (93\%) [97]. However, while improving firmness of blueberries [92-95] and blackberries [96], chitosan coatings resulted in greater loss of firmness in 'Tullmeen' raspberries [52]. Additional technical concerns that need to be addressed before edible coatings have wide commercial applications include the maintenance of the natural wax bloom which affects the desirable perceived colour of blueberries [98, 99] and overcoming the difficulty in completely drying out any residual coating materials accumulating inside the fruit hollow of picked raspberries [97].

\section{Packaging-based solutions for shelf life extension of berries}

Berries sold in the fresh market are most commonly packed in clamshells with opening ratios of 3-10\% [100]. This design is widely used in industry as it allows rapid and effective cooling of fresh produce [101], the escape of heat generated by produce respiration [102], as well as preventing ethylene accumulation [103] and moisture condensation. However, for berries with large surface area-to-volume ratios, the vents could make them more susceptible to freezing, chilling and drying damage [102]. For example, clamshells of raspberries packed in macro-perforated film with 200 holes of $3 \mathrm{~mm}$-diameter per $\mathrm{m}^{2}$ (no modified atmosphere formed) exhibited $20 \%$ higher weight loss after 14 days at $7^{\circ} \mathrm{C}$, compared to those packed in modified atmosphere films with low water vapour permeability [103]. The control was unsaleable by day 3 because of fungal growth. To address the limitations of clamshells, modified atmosphere packaging (MAP) and active packaging have been studied, both as alternative and complementary solutions. In addition, considering the high quantity of packaging needed versus berry weights, applications of eco-friendly packaging materials would make significant reductions in plastic waste and be key in meeting consumer concerns for sustainable packaging [104, 105]. An early study suggested that replacing polypropylene trays with cardboard was also beneficial in removing moisture and raspberry juice leakage [106].

\subsection{Modified atmosphere packaging (MAP)}

MAP has been used to suppress fungal decay [107, 108], reduce respiration rate [109], alter ethylene metabolism [110] and reduce weight loss (Table 2). Typical storage conditions recommended for blueberries range from 5-10\% $\mathrm{O}_{2}$ and $10-12 \% \mathrm{CO}_{2}$ at $0^{\circ} \mathrm{C}[1,17]$, while for raspberries and blackberries, they range from 5-10\% $\mathrm{O}_{2}$ and 10-20\% $\mathrm{CO}_{2}$ [3]. Softening, decolouration and development of off-flavours particularly occurred in blueberries when $\mathrm{CO}_{2}$ was higher than $15 \%[111,112]$. An average loss of firmness of $24 \mathrm{~N} \mathrm{~m}^{-1}$ was also reported in nine raspberry cultivars stored under elevated $\mathrm{CO}_{2}$ atmospheres $\left(12.5 \% \mathrm{CO}_{2}\right.$ plus $\left.7.5 \% \mathrm{O}_{2}\right)$ for 4 weeks, compared to those kept in air [108]. In contrast, fermentation and formation of off-odours (acetaldehyde, ethanol and ethyl acetate) in raspberries were induced by low $\mathrm{O}_{2}$. An $\mathrm{O}_{2}$ level over $4 \%$ at $0^{\circ} \mathrm{C}, 6 \%$ at $10^{\circ} \mathrm{C}$ or $8 \%$ at $20^{\circ} \mathrm{C}$ was suggested as being needed to prevent fermentative induction [113].

The major concern for using MAP for berries is that inappropriate designs could lead to high concentrations of $\mathrm{CO}_{2}$ and depletion of $\mathrm{O}_{2}$ over time when subject to non-optimal temperature conditions during storage. This can result in atmospheres with less oxygen than those needed to maintain basal aerobic respiration. Most commercially available plastic films are unable to maintain appropriate ratios of $\mathrm{O}_{2}$ and $\mathrm{CO}_{2}$ permeability [6]. This explains why 
Table 1

Recent studies of edible coatings on blueberries, blackberries and raspberries

\begin{tabular}{|c|c|c|c|c|}
\hline Coating materials & Cultivars & $\begin{array}{l}\text { Storage temperatures } \\
\text { and durations }\end{array}$ & $\begin{array}{l}\text { Comments on effects } \\
\text { effects }\end{array}$ & References \\
\hline \multicolumn{5}{|l|}{ BLUEBERRIES } \\
\hline Acid-soluble chitosan & 'Duke' & $\begin{array}{l}2^{\circ} \mathrm{C}, 7 \text { days }+20^{\circ} \mathrm{C}, 12 \\
\text { days }\end{array}$ & $\begin{array}{l}\downarrow 15 \% \text { decay rate } \\
\downarrow \text { weight loss } \\
\text { Retained firmness close to } \\
\quad \text { day } 0\end{array}$ & [92] \\
\hline Calcium caseinate & 'Elliot' & $\begin{array}{l}2^{\circ} \mathrm{C}, 7 \text { days }+20^{\circ} \mathrm{C}, 12 \\
\text { days }\end{array}$ & $\uparrow 25 \%$ decay rate & \\
\hline Water - soluble chitosan & 'Elliot' & $\begin{array}{l}2^{\circ} \mathrm{C}, 7 \text { days }+20^{\circ} \mathrm{C}, 15 \\
\text { days }\end{array}$ & $\begin{array}{l}\downarrow 5 \% \text { decay rate } \\
\uparrow \text { firmness }\end{array}$ & \\
\hline $\begin{array}{l}\text { Chitosan } \\
\text { Chitosan + blueberry } \\
\text { leaf and fruit extracts }\end{array}$ & 'Langfeng' & $2^{\circ} \mathrm{C}, 35$ days & $\begin{array}{l}\downarrow 15-30 \% \text { decay rate } \\
\uparrow \text { firmness } \\
\downarrow \text { weight loss } \\
\text { Retained titratable acidity } \\
\quad \text { close to day } 0 \\
\end{array}$ & [95] \\
\hline $\begin{array}{l}\text { Chitosan }+ \text { Aloe vera } \\
\text { fractions }\end{array}$ & 'Duke' & $5^{\circ} \mathrm{C}, 25$ days & $\begin{array}{c}\uparrow \text { blueberry shelf life by } \\
\text { approximately } 5 \text { days } \\
\text { Maintained soluble solid } \\
\text { contents close to day } 0 \\
\downarrow \text { losses of weight, } \\
\text { titratable acidity and pH }\end{array}$ & {$[94]$} \\
\hline Chitosan & Rabbit eye & $2^{\circ} \mathrm{C}, 35$ days & $\begin{array}{l}\text { Inhibited Botryotinia } \\
\text { fuckeliana isolated from } \\
\text { decayed berries in vitro } \\
\downarrow \text { losses of weight and } \\
\text { firmness } \\
\uparrow \text { phenolic and } \\
\text { anthocyanin contents } \\
\text { and slowed their losses }\end{array}$ & [93] \\
\hline Pullulan & 'Bluecrop' & $\begin{array}{l}16^{\circ} \mathrm{C}, 14 \text { days or } 4^{\circ} \mathrm{C}, 28 \\
\text { days }\end{array}$ & $\begin{array}{l}\downarrow 31 \% \text { decay after } 14 \\
\quad \text { days at } 16^{\circ} \mathrm{C} \\
\downarrow 7 \% \text { weight loss at } 16^{\circ} \mathrm{C} \\
\downarrow 20 \% \text { decay after } 28 \\
\quad \text { days at } 4^{\circ} \mathrm{C} \\
\end{array}$ & [137] \\
\hline $\begin{array}{l}\text { Quinoa Protein /Chitosan } \\
\text { /Sunflower oil }\end{array}$ & Not mentioned & $4^{\circ} \mathrm{C}, 35$ days & $\begin{array}{l}\downarrow \text { fungal growth by } 3 \log \\
\quad \text { CFU g } \\
\downarrow \text {-1 } \\
\downarrow 5 \% \text { weight loss } \\
\downarrow 32 \% \text { firmness } \\
\text { altered wax bloom and } \\
\quad \text { colours }\end{array}$ & [98] \\
\hline
\end{tabular}


Table 1

(Continued)

\begin{tabular}{|c|c|c|c|c|}
\hline Coating materials & Cultivars & $\begin{array}{l}\text { Storage temperatures } \\
\text { and durations }\end{array}$ & $\begin{array}{l}\text { Comments on effects } \\
\text { effects }\end{array}$ & References \\
\hline Sodium alginate & Not mentioned & $4^{\circ} \mathrm{C}, 10$ days & $\begin{array}{l}\downarrow \text { yeast counts by } 1.5-1.8 \mathrm{log} \\
\quad \mathrm{CFU} \mathrm{g} \mathrm{g}^{-1} \\
\downarrow \text { mesophilic aerobic bacteria } \\
\text { count by } 2 \log \mathrm{CFU} \mathrm{g}{ }^{-1}\end{array}$ & [99] \\
\hline Pectin & & & $\begin{array}{l}\uparrow \text { firmness } \\
\text { Caused glossy appearance }\end{array}$ & \\
\hline $\begin{array}{l}\text { Limonene } \\
\text { Limonene + liposomes }\end{array}$ & Not mentioned & $4^{\circ} \mathrm{C}, 63$ days & $\begin{array}{l}24-33 \% \text { decay incidence } \\
\downarrow 32-40 \% \text { total fruit loss }\end{array}$ & {$[138]$} \\
\hline BLACKBERRIES & & & & \\
\hline Chitosan & ‘Tupy’ & $\begin{array}{l}0^{\circ} \mathrm{C}, 18 \text { days or } 10^{\circ} \mathrm{C}, 18 \\
\text { days }\end{array}$ & $\begin{array}{l}\downarrow 45 \% \text { rot incidence after } 18 \\
\text { days at } 10^{\circ} \mathrm{C} \\
\text { Retained weights, firmness } \\
\text { close to day } 0 \text { and desirable } \\
\text { soluble solid/titratable } \\
\text { acidity ratios when stored } \\
\text { at } 0^{\circ} \mathrm{C}\end{array}$ & [96] \\
\hline $\begin{array}{l}\text { Cassava starch } \\
\text { Kefir }\end{array}$ & ‘Tupy’ & $0^{\circ} \mathrm{C}, 18$ days & $\begin{array}{l}\text { Maintained desirable soluble } \\
\text { solid/titratable acidity } \\
\text { ratios } \\
\text { Failed to prevent rot } \\
\text { incidence (reached } 100 \% \\
\text { rot after } 15 \text { days for cassava } \\
\text { starch coating and } 18 \text { days } \\
\text { for kefir coating) } \\
\text { Failed to maintain fruit } \\
\text { firmness }\end{array}$ & \\
\hline Starch-beeswax coatings & Not mentioned & $4^{\circ} \mathrm{C}, 16$ days & $\begin{array}{l}\text { Fruit cuticle integrity } \\
\uparrow \text { respiration rates, ethylene } \\
\text { production, formation of } \\
\text { volatiles related to } \\
\text { fermentation process and } \\
\text { weight loss } \\
\downarrow \text { hue value, phenolic and } \\
\text { anthocyanin contents }\end{array}$ & {$[90]$} \\
\hline \multicolumn{5}{|l|}{ RASPBERRIES } \\
\hline $\begin{array}{l}\text { Chitosan } \\
\text { Chitosan + calcium } \\
\text { gluconate }\end{array}$ & 'Tullmeen' & $2^{\circ} \mathrm{C}, 21$ days in dark & $\begin{array}{l}\downarrow 93 \% \text { decay incidence } \\
\downarrow \text { weight loss } \\
\downarrow \text { firmness } \\
\text { Delayed colour changes }\end{array}$ & [97] \\
\hline
\end{tabular}


Table 1

(Continued)

\begin{tabular}{|c|c|c|c|c|}
\hline Coating materials & Cultivars & $\begin{array}{l}\text { Storage temperatures } \\
\text { and durations }\end{array}$ & $\begin{array}{l}\text { Comments on effects } \\
\text { effects }\end{array}$ & References \\
\hline Chitosan + Vitamin E & 'Tullmeen' & $2^{\circ} \mathrm{C}, 21$ days in dark & $\begin{array}{l}\text { Altered colour (due to } \\
\text { yellowish and less } \\
\text { transparent coating } \\
\text { solution) } \\
\downarrow \text { firmness }\end{array}$ & \\
\hline Aloe vera gel & $\begin{array}{l}\text { Iranian native } \\
\text { species }\end{array}$ & $4^{\circ} \mathrm{C}, 8$ days in dark & $\begin{array}{l}\downarrow 8.5-12 \% \text { decay } \\
\text { incidence }\end{array}$ & [139] \\
\hline $\begin{array}{l}\text { Sodium alginate + eugenol } \\
\text { Sodium alginate + citral } \\
\text { Pectin + eugenol } \\
\text { Pectin + eugenol + citral }\end{array}$ & Not mentioned & $0.5^{\circ} \mathrm{C}, 15$ days & $\begin{array}{l}\text { Inhibited growths of } \\
\text { aerobic mesophilic } \\
\text { microorganisms } \\
\text { Failed to maintain } \\
\text { weights, phenolic and } \\
\text { anthocyanin contents }\end{array}$ & {$[140,141]$} \\
\hline
\end{tabular}

non-perforated films often resulted in softening in both blueberries [114] and raspberries [115-117]. In contrast, enclosed punnets to replace vented clamshells could allow $\mathrm{CO}_{2}$ accumulation during storage, but observed levels were insufficient to control fungal decay in blackberries [118]. In addition, the resistance of plastic packaging to water vapour permeation prevents water vapour due to produce transpiration escaping from the packaging and leads to moisture condensation that favours mould growth [27]. Perforated MAP could aid by accelerating gas exchange and increasing the permeability to water vapour. When LDPE films of the same thickness were used to pack $1.5 \mathrm{~kg}$ of blueberries, packages with two perforations each of $3 \mathrm{~mm}^{2}$, resulted in lower $\mathrm{CO}_{2}$ concentrations being accumulated (6.2\% versus $9.2 \%)$ and greatly reduced the percentage of soft fruits $(7.1 \%$ versus $27 \%)$, compared to the film without perforations [114]. However, commercial MAP films often have higher $\mathrm{CO}_{2}$ transmission rates than $\mathrm{O}_{2}$ transmission rates and therefore failed to create sufficient $\mathrm{CO}_{2}$ concentrations to control mould growth and delay quality losses [119]. For high-value products like berries, customised MAP bags based on produce respiration rates, produce weights, packaging properties and desirable atmospheres are currently commercially available. Industrial systems combining a device measuring the respiration rate, software to reliably calculate the numbers and sizes of microperforations, and an inline laser perforation system, are also available. Examples are PerfoTec ${ }^{\circledR}$ (PerfoTec B.V., The Netherlands) and StarMAP® (LaserMicro RofinBaaselLasertech, Germany) [120]. However, the high establishment and production costs associated with this MAP film technology may limit their commercial viability.

\subsection{Active packaging with ethylene control properties}

Trials on controlling ethylene during storage of blueberries, raspberries and blackberries have been conducted, although the roles of ethylene in quality and shelf life of these berry fruits are not fully understood. The most common ethylene scavenger is potassium permanganate $\left(\mathrm{KMnO}_{4}\right)$, which is usually embedded in silica gel at a concentration of about 4-6\%, and supplied in sealed, ethylene-permeable sachets [121] or it can also be added directly into polymeric films [122]. The ethylene action inhibitor 1-MCP can be released as a gas from sachets [123] and polymeric films when activated under high relative humidity conditions [124]. Alternatively, 1-MCP can be applied as a liquid formulation (SmartFresh ${ }^{\mathrm{TM}}$, AgroFresh, Inc.). 
Table 2

Available literature on MAP applications for blueberries, blackberries and raspberries

\begin{tabular}{|c|c|c|c|c|}
\hline $\begin{array}{l}\text { Packaging } \\
\text { specifications }\end{array}$ & $\begin{array}{c}\text { Fruit } \\
\text { variety }\end{array}$ & $\begin{array}{l}\text { Storage conditions } \\
\text { and initial atmosphere } \\
\text { atmosphere }^{\mathrm{a}}\end{array}$ & Comments on effects ${ }^{b}$ & References \\
\hline \multicolumn{5}{|l|}{ BLUEBERRIES } \\
\hline $\begin{array}{l}\text { PE film }(100 \mu \mathrm{m}) \\
\text { Biobased film }(50 \mu \mathrm{m})\end{array}$ & 'Duke' & $\begin{array}{l}1^{\circ} \mathrm{C}, 45 \text { days } \\
10 \% \mathrm{CO}_{2}+11 \% \mathrm{O}_{2} \\
\end{array}$ & $\downarrow 10 \%$ weight loss & {$[142]$} \\
\hline $\begin{array}{l}\text { LDPE gusseted bag ViewFresh }{ }^{\circledR} \\
(50 \mu \mathrm{m}), 0.02 \text { gauge } \\
2 \text { microperforations }=0.3 \mathrm{~mm}^{2}\end{array}$ & 'Brigitta' & $\begin{array}{l}0^{\circ} \mathrm{C}, 30 \text { and } 45 \text { days }+18^{\circ} \mathrm{C}, \\
1 \text { and } 3 \text { days }\end{array}$ & $\begin{array}{l}\uparrow 20-30 \% \text { sound fruits } \\
\text { Maintained firmness during } \\
\text { storage }\end{array}$ & [143] \\
\hline $\begin{array}{l}\text { LDPE }(60 \mu \mathrm{m}) \\
\text { No perforation }\end{array}$ & 'Brigitta' & $\begin{array}{l}0^{\circ} \mathrm{C} \\
30 \text { and } 45 \text { days }\end{array}$ & $\begin{array}{l}\downarrow 3 \% \text { weight loss after } 30 \text { days } \\
\text { and } 6.4 \% \text { after } 45 \text { days } \\
\uparrow 16.8 \% \text { soft fruits after } 30 \\
\text { days and } 12 \% \text { after } 45 \text { days } \\
\uparrow 5 \% \text { red berries }\end{array}$ & {$[114]$} \\
\hline $\begin{array}{l}\text { LDPE }(60 \mu \mathrm{m}) \\
\text { Two perforations }\left(3 \mathrm{~mm}^{2}\right)\end{array}$ & $\begin{array}{l}\text { 'Brigitta' } \\
\text { 'Legacy' }\end{array}$ & 30 and 45 days & $\begin{array}{l}\downarrow 3 \% \text { weight loss after } 30 \text { days } \\
\text { and } 6.4 \% \text { after } 45 \text { days } \\
\text { Maintained firmness during } \\
\text { storage } \\
\uparrow 5 \% \text { and } 10 \% \text { red berries after } \\
30 \text { and } 45 \text { days, respectively }\end{array}$ & \\
\hline \multicolumn{5}{|l|}{ BLACKBERRIES } \\
\hline $\begin{array}{l}\text { Punnet with snap-fit lid } \\
\text { Oriented poly(lactic acid) (PLA) } \\
\quad \text { VersaPack }^{\circledR}\end{array}$ & 'Cancaska' & 18 days & $\begin{array}{l}\text { Control: oriented polystyrene } \\
\text { (OPS) packaging with the } \\
\text { same design } \\
\uparrow \text { weight loss by } 1.8 \% \text { and } \\
\text { fungal growth by } 18 \% \\
\text { Control: oriented polystyrene } \\
\text { (OPS) packaging with the } \\
\text { same design } \\
\uparrow \text { weight loss by } 1.6 \%\end{array}$ & [118] \\
\hline \multicolumn{5}{|l|}{ RASPBERRIES } \\
\hline PE film $(76.2 \mu \mathrm{m})$ & $\begin{array}{l}\text { 'Qualicum' } \\
\text { 'Chilliwack' } \\
\text { 'Meeker' }\end{array}$ & $\begin{array}{l}1^{\circ} \mathrm{C}, 7 \text { days } \\
10 \% \mathrm{CO}_{2}+5 \% \mathrm{O}_{2}\end{array}$ & $\begin{array}{l}\text { Maintained the red-ripe colour } \\
\uparrow \text { softening } \\
\uparrow \text { the accumulation of volatiles } \\
\text { associated with off-odours }\end{array}$ & {$[144]$} \\
\hline $\begin{array}{l}\text { Biodegradable and compostable film } \\
\text { (non-commercial, } 25 \mu \mathrm{m})\end{array}$ & 'Himbo Top' & $\begin{array}{l}1^{\circ} \mathrm{C}, 2 \text { days }+18^{\circ} \mathrm{C}, 2 \text { days } \\
\text { Air or } \\
10 \% \mathrm{O}_{2}+10 \% \mathrm{CO}_{2}\end{array}$ & $\begin{array}{l}\text { Control: macro-perforated PP } \\
\text { film ( } 20 \mu \mathrm{m}, \text { no modified } \\
\text { atmosphere) } \\
\text { Maintained fruit colour and } \\
\text { aroma profiles close to day } 0\end{array}$ & {$[117,145]$} \\
\hline
\end{tabular}


Table 2

(Continued)

\begin{tabular}{|c|c|c|c|c|}
\hline $\begin{array}{l}\text { Packaging } \\
\text { specifications }\end{array}$ & $\begin{array}{c}\text { Fruit } \\
\text { variety }\end{array}$ & $\begin{array}{l}\text { Storage conditions } \\
\text { and initial atmosphere } \\
\text { atmosphere }^{\mathrm{a}}\end{array}$ & Comments on effects ${ }^{\mathrm{b}}$ & References \\
\hline PP film $(30 \mu \mathrm{m}$, non-perforated $)$ & 'Himbo Top' & $\begin{array}{l}1^{\circ} \mathrm{C}, 4 \text { days } \\
\text { Air or } \\
10 \% \mathrm{O}_{2}+10 \% \mathrm{CO}_{2}\end{array}$ & $\begin{array}{l}\text { Control: macro-perforated PP } \\
\text { film ( } 20 \mu \mathrm{m}, \text { no modified } \\
\text { atmosphere }) \\
\uparrow \text { softening }\end{array}$ & [117] \\
\hline $\begin{array}{l}\text { Xtend }{ }^{\circledR} \text { film (commercial MAP) } \\
\text { LDPE bags }(30 \mu \mathrm{m})\end{array}$ & 'Polka' & $\begin{array}{l}1.6^{\circ} \mathrm{C}, 4 \text { days or } \\
1.6^{\circ} \mathrm{C}, 3 \text { days }+6^{\circ} \mathrm{C}, 1 \text { days }\end{array}$ & $\begin{array}{l}\text { Maintained light red colours } \\
\text { Failed to create sufficient } \mathrm{CO}_{2} \\
\text { levels to suppress mould } \\
\text { growth }\end{array}$ & [119] \\
\hline $\begin{array}{l}\text { Master-bags made from } \\
\text { LDPE (low gas barrier) } \\
\text { LDPE/EVOH/LDPE (high gas } \\
\text { barrier) } \\
\text { with and without oxygen absorbers } \\
\end{array}$ & 'Erika' & $4^{\circ} \mathrm{C}, 7$ days & $\begin{array}{l}\text { Control: lidded PET } \\
\text { macro-perforated rigid trays } \\
\uparrow \text { softening and anaerobic } \\
\text { metabolisms }\end{array}$ & [116] \\
\hline Master-bags made from PLA & 'Erika' & days & $\begin{array}{l}\text { Control: lidded PET } \\
\text { macro-perforated rigid trays } \\
\text { Maintained colour and firmness } \\
\text { close to day } 0\end{array}$ & \\
\hline $\begin{array}{l}\text { Master-bags made from LDPE } \\
\quad(\text { medium gas barrier, } 500 \mu \mathrm{m})\end{array}$ & 'Erika' & & $\begin{array}{l}\text { Control: lidded PET } \\
\text { macro-perforated rigid trays } \\
\downarrow \text { mould growth } \\
\uparrow \text { softening and drupelet } \\
\quad \text { breakages }\end{array}$ & [115] \\
\hline $\begin{array}{l}\text { Master-bags made from LDPE (low } \\
\text { gas barrier, } 25 \mu \mathrm{m} \text { ) }\end{array}$ & 'Erika' & , 6 days & $\begin{array}{l}\text { Control: lidded PET } \\
\text { macro-perforated rigid trays } \\
\text { Maintained fruit firmness and } \\
\text { colour } \\
\uparrow \text { shelf life by } 2 \text { days }\end{array}$ & \\
\hline $\begin{array}{l}\text { Master-bags made from LDPE (low } \\
\text { gas barrier, } 25 \mu \mathrm{m})+\mathrm{CO}_{2} \text { - emitters } \\
\text { (BioFresh } ®)\end{array}$ & 'Erika' & $5^{\circ} \mathrm{C}, 8$ days & $\begin{array}{l}\text { Control: lidded PET } \\
\text { macro-perforated rigid trays } \\
\text { Maintained fruit firmness } \\
\text { during storage } \\
\uparrow \text { shelf life by } 4 \text { days }\end{array}$ & \\
\hline $\begin{array}{l}\text { Cardboard boxes }(145 \times 120 \times 80 \mathrm{~mm}) \\
\text { placed in PLA (polylactic acid) } \\
\text { film pouches of } 40 \mu \mathrm{m} \text { thickness }\end{array}$ & 'Polana' & $4^{\circ} \mathrm{C}, 14$ days & $\begin{array}{l}\downarrow \text { weight loss } \\
\text { Retain fruit colour as at harvest } \\
\text { and higher ascorbic acid } \\
\text { contents } \\
\text { Prevented condensation and } \\
\text { moisture accumulation }\end{array}$ & [106] \\
\hline
\end{tabular}

anitial atmo sphere inside packages was air (approx. $20 \% \mathrm{O}_{2}$ and $0 \% \mathrm{CO}_{2}$ ) if not mentioned. ${ }^{\mathrm{b}}$ Results were compared to fruits packed in vented clamshells unless stated otherwise. 
There has been no work solely evaluating ethylene control for shelf life extension of raspberries and blackberries. The effectiveness of ethylene control on the postharvest storability of blueberries seems to depend on the cultivar and storage durations. In 'Lanfeng' blueberries, the addition of $\mathrm{KMnO}_{4}$ sachets reduced fruit weight loss and decay during both cold storage $\left(60\right.$ days, $\left.0^{\circ} \mathrm{C}\right)$ and on-shelf display periods $\left(8\right.$ days, $\left.20^{\circ} \mathrm{C}\right)$ [125]. Fruit firmness was also retained by suppressing the activity of cell wall enzymes (pectin methyl esterase, polygalacturonase, cellulase and $\beta$-galactosidase). Likewise, 'Berkeley' blueberries exposed to 1-MCP $\left(1.0 \mu \mathrm{L} \mathrm{L}^{-1}, 18 \mathrm{~h}\right)$ showed less softening (12.3\%) than the control fruits during 8 days of storage at $4^{\circ} \mathrm{C}$ [126]. The treated fruits also showed a slower decrease in titratable acidity and soluble solid contents. Similar findings were reported for 'Lateblue' blueberries stored in air for 21 days after being treated with 1-MCP $\left(0.3 \mu \mathrm{L} \mathrm{L}^{-1}, 24 \mathrm{~h}\right)$ at $20^{\circ} \mathrm{C}$, but the advantages were not found after 28 days, or among samples stored under controlled atmosphere $\left(3 \% \mathrm{O}_{2}, 11 \%\right.$ $\mathrm{CO}_{2}$ ) for 60 days [127]. 1-MCP up to $0.4 \mu \mathrm{L} \mathrm{L}^{-1}$ for $24 \mathrm{~h}$ at $20^{\circ} \mathrm{C}$ had no influence on the shelf life quality of two other highbush cultivars ('Burlington' and 'Coville') [44]. 'Mistý' and 'Blue Cuinéx' blueberries treated with 1-MCP $\left(1.0 \mu \mathrm{L} \mathrm{L}^{-1}, 12 \mathrm{~h}\right)$ had similar respiration rates and quality attributes as the control after 14-day storage at $4{ }^{\circ} \mathrm{C}$, except for the firmness of 'Mistý', which was about 1.2 times higher than the untreated fruits [128].

Combinations of ethylene control with other methods could be beneficial through synergistic effects. For example, a permeable packaging film with an ethylene transmission rate of $1.98 \mathrm{~mL} \mathrm{~m}^{-2} \mathrm{~h}^{-1} \mathrm{kPa}^{-1}$ in combination with high-oxygen MA $\left(95 \% \mathrm{O}_{2}, 5 \% \mathrm{~N}_{2}\right)$ reduced ethylene accumulation inside raspberry packages to $37 \mu \mathrm{L} \mathrm{L}^{-1}$, compared to $60 \mu \mathrm{L} \mathrm{L}^{-1}$ in samples in high oxygen MA and high barrier film. This combination of ethylene permeable film and high oxygen MA limited mould growth after 14 days at $7^{\circ} \mathrm{C}$ with only a single mouldy fruit being found in a $150 \mathrm{~g}$ raspberry sample (approximately 40 fruits) [129]. Spraying 'Blue Cuinéx' blueberries with $10 \mathrm{~mL}$ of $1 \mathrm{mmol} \mathrm{L}^{-1} \mathrm{~S}$-nitrosoglutathione (GSNO, a NO donor) upon 1-MCP exposure had better retention of fruit firmness and ascorbic acid concentrations than either treatment alone [128]. Also, 1-MCP combined with UV-C irradiation reduced respiration rate, ethylene production, decay incidence, softening, changes in colour, titratable acid and soluble solid contents of 'Berkeley' blueberries over 8 days at $4{ }^{\circ} \mathrm{C}$ [126]. These studies using MA stores, and with scrubbers to control ethylene, could be taken forward to studies of control at the package levels.

\section{Additional approaches for shelf life extension of berries}

As detailed in Table 3, a range of alternative approaches have been trialled and have shown some success for shelf life extension of blueberries and raspberries. These technologies include sanitisation using electrolysed water (EW) and hydrogen peroxide, and high $\mathrm{O}_{2}$ (superatmospheric $\left.\mathrm{O}_{2}, 70-100 \%\right)$ and/or high $\mathrm{CO}_{2}(>20 \%)$.

Electrolysed water $(\mathrm{EW})$ is generated from the electrolysis of $\mathrm{NaCl}$ solutions producing mainly hypochlorous acid and has shown to be a safe, effective and inexpensive sanitiser for a range of fruits and vegetables (reviewed by Rahman et al., 2016) [130]. Acidic electrolysed water (AEW, pH 2.3-2.7) has been shown to efficiently sanitise blueberries (Table 3), but the application of AEW to fresh sensitive produce is limited by its acidic property [131]. These concerns have shifted industry focus toward using neutral electrolysed water ( $\mathrm{pH} 6-8$ ), which has similar antimicrobial effects to AEW but with fewer associated risks to produce physiology [72, 131].

Hydrogen peroxide $\left(\mathrm{H}_{2} \mathrm{O}_{2}\right)$ is also a strong oxidiser that can be used in either aqueous or vapour form at concentrations between 1-5\%. $\mathrm{H}_{2} \mathrm{O}_{2}$ is safe as the compound quickly decomposes to water and oxygen [132]. Although only a few successes have been reported for the use of $\mathrm{H}_{2} \mathrm{O}_{2}$ as a postharvest sanitiser for fresh produce, positive results were obtained in blueberries [133] (Table 3). However, the oxidation of anthocyanins, and therefore, changes in fruit colour and decrease in antioxidant properties, could be a critical drawback of $\mathrm{H}_{2} \mathrm{O}_{2}$ technology in berries [134].

\section{Conclusion}

It is possible to extend the shelf life of blueberries, raspberries and blackberries by applying novel postharvest technologies together with good temperature and RH control. However, as highlighted in this review, there are still 
Table 3

Additional approaches for shelf life extension of berries

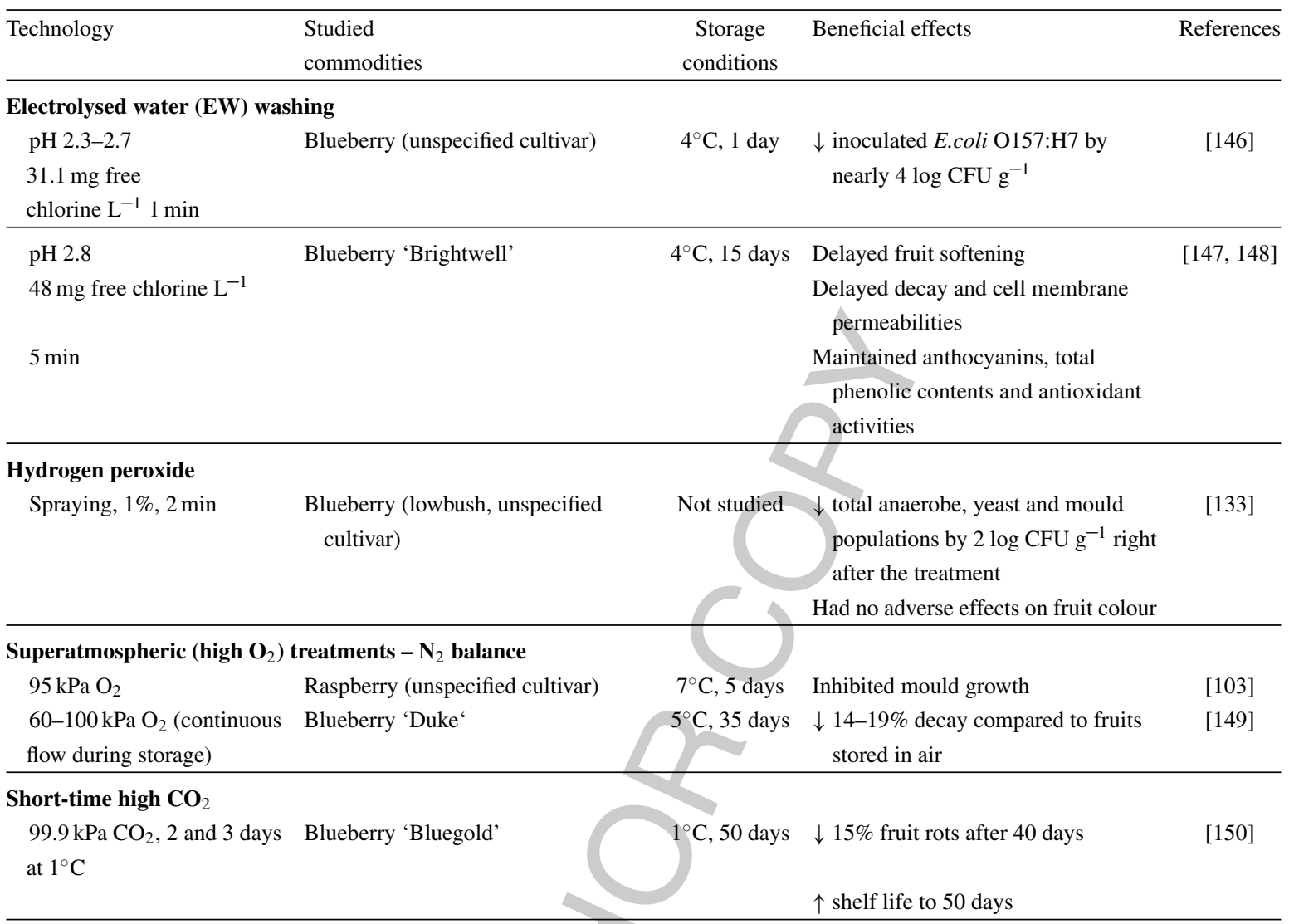

knowledge gaps and challenges that will need to be addressed. For raspberries and blackberries, the application of novel technologies is limited by their fragile drupelet structures and higher respiration rates. Potentially for these berries, gas-based sanitisation (particularly $\mathrm{SO}_{2}$ and $\mathrm{ClO}_{2}$ ) and UV-B irradiation treatments avoid the application of water and will offer the most benefits in terms of shelf life extension. In contrast, blueberries, characterised by their more robust structure and lower respiration rates, will benefit from additional options such as aqueous sanitisers, mild heat treatments and edible coatings. The latter two, however, are often limited by their adverse effects on appearance of blueberry wax blooms.

Applications of the reviewed technologies as combination hurdle treatments could increase their effectiveness for shelf life extension compared to individual technologies alone. For example, MAP pallet liners combined with sanitisation methods might reduce weight loss, retain sensorial quality and prevent fungal decay. As raspberries are ethylene sensitive, MAP combined with ethylene control could be considered to delay fruit senescence, as demonstrated in strawberries [135]. Other new technologies, such as packaging for minimising mechanical damage induced by vibrational effects, will arguably become more important as supply chains lengthen. While there are current packaging options that mitigate vibration damage, their efficacy for extending the shelf life of berries will need to be evaluated.

Lastly, while consumers' purchasing behaviour at retail is strongly determined by visual appearance, it will be flavours and texture that will determine consumers' acceptance and repeat purchasing behaviour [136]. Therefore, 
it will be necessary to investigate more explicitly how the reviewed technologies affect sensorial properties and consumer acceptability, which is currently lacking.

\section{Acknowledgments}

This work was supported by the Australian Research Council's Industrial Transformation Training Centres scheme under Grant IC140100024.

We thank Michele Buntain for valuable comments on an earlier draft of the manuscript.

\section{Conflict of interest}

The authors have no conflict of interest to report.

\section{Funding}

The authors report no funding.

\section{References}

[1] Mitcham E. Quality of berries associated with preharvest and postharvest conditions. In: Zhao Y, editor. Berry fruit: Value-added products for health promotion. New York: CRC Press; 2007. p. 207.

[2] Sobekova K, Thomsen MR, Ahrendsen BL. Market trends and consumer demand for fresh berries. Appl Stud Agribusiness and Commer. 2013;7:11-4.

[3] Bower C. Postharvest handling, storage, and treatment of fresh market berries. In: Zhao Y, editor. Quality of berries associated with preharvest and postharvest conditions. New York: CRC Press; 2007. p. 261.

[4] Hancock J, Callow P, Serçe S, Hanson E, Beaudry R. Effect of cultivar, controlled atmosphere storage, and fruit ripeness on the long-term storage of highbush blueberries. HortTechnology. 2008;18(2):199-205. doi:10.21273/HORTTECH.18.2.199

[5] Kumar S, Baghel M, Yadav A, Dhakar MK. Postharvest biology and technology of berries. In: Mir SA, Shah MA, Mir MM, editors. Postharvest biology and technology of temperate fruits. Cham, Switzerland: Springer; 2018. p. 349-70.

[6] Mahajan BVC, Pongener A. Post-harvest handling and storage. In: Sharma RM, Yamdagni R, Dubey AK, Pandey V, editors. Strawberries: Production, postharvest management and protection. New York: CRC Press; 2019. p. 411-30.

[7] Parvez S, Wani IA. Postharvest biology and technology of strawberry. In: Mir SA, Shah MA, Mir MM, editors. Postharvest biology and technology of temperate fruits. Cham, Switzerland: Springer; 2018. p. 331-48.

[8] Lafarga T, Colás-Medà P, Abadias M, Aguiló-Aguayo I, Bobo G, Viñas I. Strategies to reduce microbial risk and improve quality of fresh and processed strawberries: A review. Innov Food Sci Emerg Technol. 2019;52:197-212. doi:10.1016/j.ifset.2018.12.012

[9] Vicente AR, Civello PM, Martínez GA, Powell ALT, Labavitch JM, Chaves AR. Control of postharvest spoilage in soft fruit. Stewart Postharvest Rev. 2005;1(4):1-11. doi:10.2212/spr.2005.4.1

[10] Vicente AR, Sozzi GO. Ripening and postharvest storage of 'soft fruits'. Fruit, Veg Cereal Sci Biotech. 2007;1:95-103.

[11] Mulderij R. Overview global market berries [Internet]. Tholen, The Netherlands: Fresh Plaza; 2016 [updated 2016 Apr 29 ; cited 2019 Jun 19]. Available from: https://www.freshplaza.com/article/2157238/overview-global-market-berries/

[12] Perkins-Veazie P. Blackberry. In: Gross KC, Wang CY, Saltveit M, editors. The commercial storage of fruits, vegetables, and florist and nursery stocks. 66 [Internet]. Washington: United States Department of Agriculture, Agricultural Research Service; 2016. [cited 2019 Jun 19] p. 237-9. Available from: https://www.ars.usda.gov/ARSUserFiles/oc/np/CommercialStorage/CommercialStorage.pdf

[13] Perkins-Veazie P. Blueberry. In: Gross KC, Wang CY, Saltveit M, editors. The commercial storage of fruits, vegetables, and florist and nursery stocks. 66 [Internet]. Washington, DC: United States Department of Agriculture, Agricultural Research Service; 2016. [cited 2019 Jun 19] p. 240-2. Available from: https://www.ars.usda.gov/ARSUserFiles/oc/np/CommercialStorage/CommercialStorage.pdf 
[14] Perkins-Veazie P. Raspberry. In: Gross KC, Wang CY, Saltveit M, editors. The commercial storage of fruits, vegetables, and florist and nursery stocks. 66 [Internet]. Washington, DC: United States Department of Agriculture, Agricultural Research Service; 2016. [cited 2019 Jun 19] p. 530-2. Available from: https://www.ars.usda.gov/ARSUserFiles/oc/np/CommercialStorage/CommercialStorage.pdf

[15] Perkins-Veazie P, Collins J, Clark J. Shelf-life and quality of 'Navaho' and 'Shawnee' blackberry fruit stored under retail storage conditions. J Food Qual. 1999;22(5):535-44. doi:10.1111/j.1745-4557.1999.tb00184.x

[16] Retamales JB, Hancock JF. Blueberries. 2nd ed. Oxford: Cabi; 2018.

[17] Paniagua A, East A, Heyes J. Interaction of temperature control deficiencies and atmosphere conditions during blueberry storage on quality outcomes. Postharvest Biol Technol. 2014;95:50-9. doi:10.1016/j.postharvbio.2014.04.006

[18] Jackson ED, Sanford KA, Lawrence RA, McRae KB, Stark R. Lowbush blueberry quality changes in response to prepacking delays and holding temperatures. Postharvest Biol Technol. 1999;15(2):117-26. doi:10.1016/S0925-5214(98)00075-1

[19] Perkins-Veazie P, Collins JK, Clark JR, Magee J. Postharvest quality of southern highbush blueberries. Proc Fla State Hort Soc. 1994;107:269-71.

[20] Miller WR, McDonald RE, Crocker TE. Fruit quality of rabbiteye blueberries as influenced by weekly harvests, cultivars, and storage duration. HortScience. 1988;23:182-4.

[21] Chu W, Gao H, Cao S, Fang X, Chen H, Xiao S. Composition and morphology of cuticular wax in blueberry (Vaccinium spp.) fruits. Food Chem. 2017;219:436-42. doi:doi.org/10.1016/j.foodchem.2016.09.186

[22] Chu W, Gao H, Chen H, Fang X, Zheng Y. Effects of cuticular wax on the postharvest quality of blueberry fruit. Food Chem. 2018;239:68-74. doi:10.1016/j.foodchem.2017.06.024

[23] United States Department of Agriculture. Agricultural Marketing Service. Blueberries. Shipping point and market inspection instructions. Washington:1998 [updated 2002 Oct; cited 2019 Jun 19]. Available from: https://www.ams.usda.gov/ sites/default/files/media/Blueberry_Inspection_Instructions\%5B1\%5D.pdf

[24] United States Department of Agriculture. Agricultural Marketing Service. Strawberries and other berries. Shipping point and market inspection instructions. Washington: 2004 [cited 2019 Jun 19]. Available from: https://www.ams.usda. gov/sites/default/files/media/Fresh_Strawberry\%2C_Raspberry\%2C_Blackberry-Dewberry_Inspection_Instructions\%5B1\%5D.pdf

[25] Caruso FL, Ramsdell DC. Compendium of blueberry and cranberry diseases. St Paul: APS Press; 1995.

[26] Tournas VH, Katsoudas E. Mould and yeast flora in fresh berries, grapes and citrus fruits. Int J Food Microbiol. 2005;105(1):11-7. doi:10.1016/j.ijfoodmicro.2005.05.002

[27] Horvitz S. Postharvest handling of berries. In: Kahramanoglu I, editor. Postharvest Handling [Internet]. London: IntechOpen; 2017. [cited 2019 Jun 19]. p. 107-23. Available from: https://www.intechopen.com/books/postharvest-handling/postharvest-handling-ofberries

[28] do Nascimento Nunes MCN, Emond J-P, Brecht JK. Quality curves for highbush blueberries as a function of the storage temperature. Small Fruits Rev. 2004;3(3-4):423-40. doi:10.1300/J301v03n03_18

[29] Sjulin TM, Robbins J. Effects of maturity, harvest date, and storage time on postharvest quality of red raspberry fruit. J Am Soc Hort Sci. 1987;112(3):481-7.

[30] do Nascimento Nunes MC. Soft fruits and berries. In: do Nascimento Nunes MC, editor. Color atlas of postharvest quality of fruits and vegetables. Ames: John Wiley \& Sons; 2009. p. 147-73.

[31] Perkins-Veazie P, Collins JK, Clark JR. Cultivar and maturity affect postharvest quality of fruit from erect blackberries. HortScience. 1996;31(2):258-61.

[32] McCoy JE, Clarke JR, Salgado AA, Jecmen A. Evaluation of harvest time/temperature and storage temperature on postharvest incidence of red drupelet reversion development and firmness of blackberry (Rubus L. subgenus Rubus Watson). Discovery Student J Dale Bumpers College of Agric, Food and Life Sci. University of Arkansas. System Division of Agriculture. 2016;17(1):59-65.

[33] Nunes CN, Emond JP. Relationship between weight loss and visual quality of fruits and vegetables. Proc Fla State Hort Soc; Florida, United States, 2007, p. 235-45.

[34] Paniagua AC, East AR, Hindmarsh JP, Heyes JA. Moisture loss is the major cause of firmness change during postharvest storage of blueberry. Postharvest Biol Technol. 2013;79:13-9. doi:10.1016/j.postharvbio.2012.12.016

[35] Chen H, Cao S, Fang X, Mu H, Yang H, Wang X, et al. Changes in fruit firmness, cell wall composition and cell wall degrading enzymes in postharvest blueberries during storage. Sci Hortic. 2015;188:44-8. doi:10.1016/j.scienta.2015.03.018

[36] Talcott ST. Chemical components of berry fruits. In: Zhao Y, editor. Berry fruit: Value-added products for health promotion. Boca Raton: CRC Press; 2007. p. 51.

[37] Iannetta PPM, Van Den Berg J, Wheatley RE, McNicol RJ, Davies HV. The role of ethylene and cell wall modifying enzymes in raspberry (Rubus idaeus) fruit ripening. Physiol Plant. 1999;105(2):337-46. doi:10.1034/j.1399-3054.1999.105220.x

[38] Perkins-Veazie P, Clark J, Huber D, Baldwin E. Ripening physiology in 'Navaho' thornless blackberries: Color, respiration, ethylene production, softening, and compositional changes. J Am Soc Hort Sci. 2000;125(3):357-63. 
[39] Paul V, Pandey R, Srivastava GC. The fading distinctions between classical patterns of ripening in climacteric and non-climacteric fruit and the ubiquity of ethylene — an overview. J Food Sci Technol. 2012;49(1):1-21. doi:10.1007/s13197-011-0293-4

[40] Kader AA. Ethylene-induced senescence and physiological disorders in harvested horticultural crops. HortScience. 1985;20(1):54-7.

[41] Bushway LJ, Pritts MP, Handley DT. Raspberry and blackberry production guide for the Northeast, midwest, and Eastern Canada. New York: NRAES; 2008.

[42] Palonen P, Weber C. Fruit color stability, anthocyanin content, and shelf life were not correlated with ethylene production rate in five primocane raspberry genotypes. Sci Hortic. 2019;247:9-16. doi:10.1016/j.scienta.2018.11.088

[43] Walsh CS, Popenoe J, Solomos T. Thornless blackberry is a climacteric fruit HortScience. 1983;4(1):482-3.

[44] DeLong JM, Prange RK, Bishop C, Harrison PA, Ryan DA. The influence of 1-MCP on shelf-life quality of highbush blueberry. HortScience. 2003;38(3):417-8. doi:10.21273/HORTSCI.38.3.417

[45] MacLean DD, NeSmith DS. Rabbiteye blueberry postharvest fruit quality and stimulation of ethylene production by 1methylcyclopropene. HortScience. 2011;46(9):1278-81. doi:10.21273/HORTSCI.46.9.1278

[46] Mahajan PV, Caleb OJ, Singh Z, Watkins CB, Geyer M. Postharvest treatments of fresh produce. Philos Trans A Math Phys Eng Sci. 2014;372:20130309. doi:10.1098/rsta.2013.0309

[47] Zhao J, Impaprasert R, Yu L, Li J, Srzednicki G. Evaluation of postharvest quality of three southern highbush blueberry (Vaccinium corymbosum hybrid) cultivars subjected to heat pre-treatment. Acta Hortic. 2012;1011:187-95. doi:10.17660/ActaHortic.2013.1011.22

[48] Fan L, Forney C, Song J, Doucette C, Jordan M, McRae K, et al. Effect of hot water treatments on quality of highbush blueberries. J Food Sci. 2008;73(6):M292-M7. doi:10.1111/j.1750-3841.2008.00838.x

[49] Wszelaki AL, Mitcham EJ. Effect of combinations of hot water dips, biological control and controlled atmospheres for control of gray mold on harvested strawberries. Postharvest Biol Technol. 2003;27(3):255-64. doi:10.1016/S0925-5214(02)00095-9

[50] Bintsis T, Litopoulou-Tzanetaki E, Robinson RK. Existing and potential applications of ultraviolet light in the food industry - A critical review. J Sci Food Agric. 2000;80(6):637-45. doi:10.1002/(SICI)1097-0010(20000501)80:6<637::AID-JSFA603>3.0.CO;2-1

[51] Sastry SK, Datta AK, Worobo RW. Ultraviolet light. J Food Sci. 2000;65:90-2. doi:10.1111/j.1750-3841.2000.tb00623.x

[52] Kim C, Hung YC. Inactivation of E. coli O157: H7 on blueberries by electrolyzed water, ultraviolet light, and ozone. J Food Sci. 2012;77(4):M206-M11. doi:10.1111/j.1750-3841.2011.02595.x

[53] Perkins-Veazie P, Collins JK, Howard L. Blueberry fruit response to postharvest application of ultraviolet radiation. Postharvest Biol Technol. 2008;47(3):280-5. doi:10.1016/j.postharvbio.2007.08.002

[54] Adhikari A, Syamaladevi RM, Killinger K, Sablani SS. Ultraviolet-C light inactivation of Escherichia coli O157: H7 and Listeria monocytogenes on organic fruit surfaces. Int J Food Microbiol. 2015;210:136-42. doi:10.1016/j.ijfoodmicro.2015.06.018

[55] Ramos B, Miller F, Brandão TR, Teixeira P, Silva CL. Fresh fruits and vegetables—an overview on applied methodologies to improve its quality and safety. Innov Food Sci Emerg Technol. 2013;20:1-15. doi:10.1016/j.ifset.2013.07.002

[56] Vicente A, Repice B, Martínez G, Chaves A, Civello P, Sozz G. Maintenance of fresh boysenberry fruit quality with UVC light and heat treatments combined with low storage temperature. J Horticul Sci and Biotechnol. 2004;79(2):246-51. doi:10.1080/14620316.2004.11511756

[57] Wang CY, Chen CT, Wang SY. Changes of flavonoid content and antioxidant capacity in blueberries after illumination with UV-C. Food Chem. 2009;117(3):426-31. doi:10.1016/j.foodchem.2009.04.037

[58] Nguyen CTT, Kim J, Yoo KS, Lim S, Lee EJ. Effect of prestorage UV-A, -B, and -C radiation on fruit quality and anthocyanin of 'Duke 'blueberries during cold storage. J Agric Food Chem. 2014;62(50):12144-51. doi:10.1021/jf504366x

[59] Eichholz I, Huyskens-Keil S, Keller A, Ulrich D, Kroh LW, Rohn S. Uv-b-induced changes of volatile metabolites and phenolic compounds in blueberries (Vaccinium corymbosum L.). Food Chem. 2011;126(1):60-4. doi:10.1016/j.foodchem.2010.10.071

[60] Basiouny FM. Effects of UV-B irradiance on storability and quality of blackberry. Proc Fla State Hort Soc. 1998;111:283-5.

[61] Oms-Oliu G, Martín-Belloso O, Soliva-Fortuny R. Pulsed light treatments for food preservation. A review. Food Bioprocess Technol. 2010;3(1):13-23. doi:10.1007/s11947-008-0147-x

[62] Bialka KL, Demirci A. Decontamination of Escherichia coli O157: H7 and Salmonella enterica on blueberries using ozone and pulsed UV-light. J Food Sci. 2007;72(9):M391-M6. doi:10.1111/j.1750-3841.2007.00517.x

[63] Bialka K, Demirci A. Efficacy of pulsed UV-light for the decontamination of Escherichia coli O157: H7 and Salmonella spp. on raspberries and strawberries. J Food Sci. 2008;73(5):M201-M7. doi:10.1111/j.1750-3841.2008.00743.x

[64] Huang Y, Chen H. A novel water-assisted pulsed light processing for decontamination of blueberries. Food Microbiol. 2014;40:1-8. doi:10.1016/j.fm.2013.11.017

[65] Xu W, Wu C. The impact of pulsed light on decontamination, quality, and bacterial attachment of fresh raspberries. Food Microbiol. 2016;57:135-43. doi:10.1016/j.fm.2016.02.009

[66] Huang Y, Sido R, Huang R, Chen H. Application of water-assisted pulsed light treatment to decontaminate raspberries and blueberries from Salmonella. Int J Food Microbiol. 2015;208:43-50. doi:10.1016/j.ijfoodmicro.2015.05.016 
[67] Popa I, Hanson EJ, Todd ECD, Schilder AC, Ryser ET. Efficacy of chlorine dioxide gas sachets for enhancing the microbiological quality and safety of blueberries. J Food Prot. 2007;70(9):2084-8. doi:10.4315/0362-028X-70.9.2084

[68] Cantín CM, Minas IS, Goulas V, Jiménez M, Manganaris GA, Michailides TJ, et al. Sulfur dioxide fumigation alone or in combination with $\mathrm{CO}_{2}$-enriched atmosphere extends the market life of highbush blueberry fruit. Postharvest Biol Technol. 2012;67:84-91. doi:10.1016/j.postharvbio.2011.12.006

[69] Rivera SA, Zoffoli JP, Latorre BA. Infection risk and critical period for the postharvest control of gray mold (Botrytis cinerea) on blueberry in Chile. Plant Dis. 2013;97(8):1069-74. doi:10.1094/PDIS-12-12-1112-RE

[70] Tarnavölgyi G. Analysis of consumers attitudes towards food additives using focus group survey. Agric Conspec Sci. 2003;68(3): 1936 .

[71] Santos MC, Nunes C, Saraiva JA, Coimbra MA. Chemical and physical methodologies for the replacement/reduction of sulfur dioxide use during winemaking: Review of their potentialities and limitations. Eur Food Res Technol. 2012;234(1):1-12. doi:10.1007/s00217011-1614-6

[72] Joshi K, Mahendran R, Alagusundaram K, Norton T, Tiwari BK. Novel disinfectants for fresh produce. Trends Food Sci Tech. 2013;34(1):54-61. doi:10.1016/j.tifs.2013.08.008

[73] Wu VC-H. Chlorine dioxide $\left(\mathrm{ClO}_{2}\right)$. In: Siddiqui M, Ayala Zavala J, Hwang C, editors. Postharvest management approaches for maintaining quality of fresh produce. Cham, Switzerland: Springer; 2016, p. 209-18.

[74] United States Department of Food and Drug Administration. Code of Federal Regulations. Secondary direct food additives permitted in food for human consumption. Chlorine dioxide. 21CFR173.300. Washington; 2018 [updated 2018 April 1; cited 2019 Jun 19]. Available from: https://www.accessdata.fda.gov/scripts/cdrh/cfdocs/cfcfr/cfrsearch.cfm?fr=173.300

[75] Xu F, Wang S, Xu J, Liu S, Li G. Effects of combined aqueous chlorine dioxide and UV-C on shelf-life quality of blueberries. Postharvest Biol Technol. 2016;117:125-31. doi:10.1016/j.postharvbio.2016.01.012

[76] Wu VCH, Kim B. Effect of a simple chlorine dioxide method for controlling five foodborne pathogens, yeasts and molds on blueberries. Food Microbiol. 2007;24(7-8):794-800. doi:10.1016/j.fm.2007.03.010

[77] Chun HH, Kang JH, Song KB. Effects of aqueous chlorine dioxide treatment and cold storage on microbial growth and quality of blueberries. J Korean Soc Appl Biol Chem. 2013;56(3):309-15. doi:10.1007/s13765-013-3017-9

[78] Sy KV, McWatters KH, Beuchat LR. Efficacy of gaseous chlorine dioxide as a sanitizer for killing Salmonella, yeasts, and molds on blueberries, strawberries, and raspberries. J Food Prot. 2005;68(6):1165-75. doi:10.4315/0362-028X-68.6.1165

[79] Maghenzani M, Chiabrando V, Giuggioli N, Peano C, Giacalone G. Chlorine dioxide gas treatment on postharvest quality of raspberry. Ital J Food Sci. 2017;29(3):476-86. doi:10.14674/IJFS-692

[80] Chiabrando V, Peano C, Beccaro G, Bounous G, Rolle L. Postharvest quality of highbush blueberry (Vaccinium corymbosum L.) cultivars in relation to storage methods. Acta Hortic. 2006;715:545-51. doi:10.17660/ActaHortic.2006.715.84

[81] Song J, Fan L, Forney CF, Jordan MA, Hildebrand PD, Kalt W, et al. Effect of ozone treatment and controlled atmosphere storage on quality and phytochemicals in highbush blueberries. Acta Hortic. 2003;600:417-23. doi:10.17660/ActaHortic.2003.600.62

[82] Giuggioli N, Briano R, Girgenti V, Peano C. Quality effect of ozone treatment for the red raspberries storage. Chem Eng Trans. 2015;44:25-30. doi:10.3303/CET1544005

[83] Barth MM, Zhou C, Mercier J, Payne FA. Ozone storage effects on anthocyanin content and fungal growth in blackberries. J Food Sci. 1995;60(6):1286-8. doi:10.1111/j.1365-2621.1995.tb04575.x

[84] Furlan VJM, Corrêa APA, Espírito Santo MLP, Zambiazi RC, Luvielmo MdM, Carbonera N. Total phenols, antioxidant activity and microbiological quality of ozone sanitized blackberry (Rubus spp. L.). Adv J Food Sci Technol. 2011;3(6):436-41.

[85] United States Department of Food and Drug Administration. Code of Federal Regulations. Code of Federal Regulations. Direct food substances affirmed as Generally Recognized As Safe. Ozone. 21CFR184.1563 [revised 2018 April 1; cited 2019 Jun 19]. Available from: https://www.accessdata.fda.gov/scripts/cdrh/cfdocs/cfcfr/CFRSearch.cfm?fr=184.1563.

[86] Concha-Meyer A, Eifert JD, Williams RC, Marcy JE, Welbaum GE. Shelf life determination of fresh blueberries (Vaccinium corymbosum) stored under controlled atmosphere and ozone. Int J Food Sci. 2015. doi:10.1155/2015/164143

[87] Wills RBH, Golding JB. Reduction of energy usage in postharvest horticulture through management of ethylene. J Sci Food Agric. 2015;95(7):1379-84. doi:10.1002/jsfa.6930

[88] Guzel-Seydim ZB, Greene AK, Seydim A. Use of ozone in the food industry. LWT-Food Sci Technol. 2004;37(4):453-60. doi:10.1016/j.lwt.2003.10.014

[89] Oliveira DM, Kwiatkowski A, Rosa CILF, Clemente E. Refrigeration and edible coatings in blackberry (Rubus spp.) conservation. J Food Sci Technol. 2014;51(9):2120-6. doi:10.1007/s13197-012-0702-3

[90] Pérez-Gallardo A, García-Almendárez B, Barbosa-Cánovas G, Pimentel-González D, Reyes-González LR, Regalado C. Effect of starch-beeswax coatings on quality parameters of blackberries (Rubus spp.). J Food Sci Technol. 2015;52(9):5601-10. doi:10.1007/s13197-014-1665-3 
[91] Romanazzi G, Feliziani E, Baños SB, Sivakumar D. Shelf life extension of fresh fruit and vegetables by chitosan treatment. Crit Rev Food Sci Nutr. 2017;57(3):579-601. doi:10.1080/10408398.2014.900474

[92] Duan J, Wu R, Strik BC, Zhao Y. Effect of edible coatings on the quality of fresh blueberries (Duke and Elliott) under commercial storage conditions. Postharvest Biol Technol. 2011;59(1):71-9. doi:10.1016/j.postharvbio.2010.08.006

[93] Jiang H, Sun Z, Jia R, Wang X, Huang J. Effect of chitosan as an antifungal and preservative agent on postharvest blueberry. J Food Qual. 2016;39(5):516-23. doi:10.1111/jfq.12211

[94] Vieira JM, Flores-López ML, de Rodríguez DJ, Sousa MC, Vicente AA, Martins JT. Effect of chitosan-Aloe vera coating on postharvest quality of blueberry (Vaccinium corymbosum) fruit. Postharvest Biol Technol. 2016;116:88-97. doi:10.1016/j.posthar vbio.2016.01.011

[95] Yang G, Yue J, Gong X, Qian B, Wang H, Deng Y, et al. Blueberry leaf extracts incorporated chitosan coatings for preserving postharvest quality of fresh blueberries. Postharvest Biol Technol. 2014;92:46-53. doi:10.1016/j.postharvbio.2014.01.018

[96] Oliveira DM, Rosa CILF, Kwiatkowski A, Clemente E. Biodegradable coatings on the postharvest of blackberry stored under refrigeration. Rev Ciênc Agron. 2013;44(2):302-9. doi:10.1590/S1806-66902013000200012

[97] Han C, Zhao Y, Leonard S, Traber M. Edible coatings to improve storability and enhance nutritional value of fresh and frozen strawberries (Fragaria $\times$ ananassa) and raspberries (Rubus ideaus). Postharvest Biol Technol. 2004;33(1):67-78. doi:10.1016/j.postharvbio.2004.01.008

[98] Abugoch L, Tapia C, Plasencia D, Pastor A, Castro-Mandujano O, López L, et al. Shelf-life of fresh blueberries coated with quinoa protein/chitosan/sunflower oil edible film. J Sci Food Agric. 2016;96(2):619-26. doi:10.1002/jsfa.7132

[99] Mannozzi C, Tylewicz U, Chinnici F, Siroli L, Rocculi P, Dalla Rosa M, et al. Effects of chitosan based coatings enriched with procyanidin by-product on quality of fresh blueberries during storage. Food Chem. 2018;251:18-24. doi:10.1016/j.foodchem.2018. 01.015

[100] Bautista N, Yang WQ. Evaluation of postharvest quality of three commercial blueberry (Vaccinium corymbosum) cultivars stored in two different types of clamshells. Int J of Fruit Sci. 2012;12(1-3):75-82. doi:10.1080/15538362.2011.619131

[101] de Castro LR, Vigneault C, Cortez LA. Cooling performance of horticultural produce in containers with peripheral openings. Postharvest Biol Technol. 2005;38(3):254-61. doi:10.1016/j.postharvbio.2005.07.004

[102] Pathare PB, Opara UL, Vigneault C, Delele MA, Al-Said FA-J. Design of packaging vents for cooling fresh horticultural produce. Food Bioprocess Technol. 2012;5(6):2031-45. doi:10.1007/s11947-012-0883-9

[103] Van der Steen C, Jacxsens L, Devlieghere F, Debevere J. Combining high oxygen atmospheres with low oxygen modified atmosphere packaging to improve the keeping quality of strawberries and raspberries. Postharvest Biol Technol. 2002;26(1):49-58. doi:10.1016/S0925-5214(02)00005-4

[104] Terry LA, Mena C, Williams A, Jenney N, Whitehead P. Fruit and vegetable resource maps: Mapping fruit and vegetable waste through the wholesale supply chain. WRAP, RC008; 2011.

[105] Wilson MD, Stanley RA, Eyles A, Ross T. Innovative processes and technologies for modified atmosphere packaging of fresh and fresh-cut fruits and vegetables. Crit Rev Food Sci Nutr. 2019;59(3):411-22. doi:10.1080/10408398.2017.1375892

[106] Seglina D, Krasnova I, Heidemane G, Kampuse S, Dukalska L, Kampuss K. Packaging technology influence on the shelf life extension of fresh raspberries. Acta Hortic. 2010;877:433-40. doi:10.17660/ActaHortic.2010.877.56

[107] Forney C. Postharvest issues in blueberry and cranberry and methods to improve market-life. Acta Hortic. 2009;810:785-98. doi:10.17660/ActaHortic.2009.810.105

[108] Forney CF, Jamieson AR, Pennell KDM, Jordan MA, Fillmore SA. Relationships between fruit composition and storage life in air or controlled atmosphere of red raspberry. Postharvest Biol Technol. 2015;110:121-30. doi:10.1016/j.postharvbio.2015.07.017

[109] Haffner K, Rosenfeld HJ, Skrede G, Wang L. Quality of red raspberry Rubus idaeus L. cultivars after storage in controlled and normal atmospheres. Postharvest Biol Technol. 2002;24(3):279-89. doi:10.1016/S0925-5214(01)00147-8

[110] Watkins CB, Zhang J. Metabolic responses of fruit to carbon dioxide. Acta Hortic. 1998;464:345-50. doi:10.17660/ActaHortic. 1998.464.52

[111] Forney C, Jordan M, Nicholas K. Effect of $\mathrm{CO}_{2}$ on physical, chemical, and quality changes in 'Burlington' blueberries. Acta Hortic. 2003;600:587-93. doi:10.17660/ActaHortic.2003.600.88

[112] Harb J, Streit J. Controlled atmosphere storage of highbush blueberries cv. 'Duke'. Eur J Hort Sci. 2004;69(2):66-72.

[113] Joles DW, Cameron AC, Shirazi A, Petracek PD, Beaudry RM. Modified-atmosphere packaging of 'Heritage' red raspberry fruit: Respiratory response to reduced oxygen, enhanced carbon dioxide, and temperature. J Am Soc Hort Sci. 1994;119(3):540-5. doi:10.21273/JASHS.119.3.540

[114] Rodriguez J, Zoffoli JP. Effect of sulfur dioxide and modified atmosphere packaging on blueberry postharvest quality. Postharvest Biol Technol. 2016;117:230-8. doi:10.1016/j.postharvbio.2016.03.008

[115] Adobati A, Uboldi E, Franzetti L, Limbo S. Shelf life extension of raspberry: Passive and active modified atmosphere inside master bag solutions. Chem Eng Trans. 2015;44:337-42. doi:10.3303/CET1544057 
[116] Giovanelli G, Limbo S, Buratti S. Effects of new packaging solutions on physico-chemical, nutritional and aromatic characteristics of red raspberries (Rubus idaeus L.) in postharvest storage. Postharvest Biol Technol. 2014;98:72-81. doi:10.1016/j.postharvbio. 2014.07.002

[117] Peano C, Girgenti V, Palma A, Fontanella E, Giuggioli NR. Film type and map on cv. Himbo top raspberry fruit quality, composition and volatiles. Ital J Food Sci. 2013;25(4):421.

[118] Joo M, Lewandowski N, Auras R, Harte J, Almenar E. Comparative shelf life study of blackberry fruit in bio-based and petroleumbased containers under retail storage conditions. Food Chem. 2011;126(4):1734-40. doi:10.1016/j.foodchem.2010.12.071

[119] Moor U, Põldma P, Tõnutare T, Moor A, Starast M. The effect of modified atmosphere storage on the postharvest quality of the raspberry 'Polka'. Agron Res. 2009;12(3):745-52.

[120] Ali WA, Gul K, Singh P. Modified atmosphere packaging of fresh produce. In: Siddiqui M. W, Rahman MS, Ali WA, editors. Innovative packaging of fruits and vegetables. Strategies for safety and quality maintenance. Ontario, Canada: Apple Academic Press; 2018, p. 29-48.

[121] Wyrwa J, Barska A. Innovations in the food packaging market: Active packaging. Eur Food Res Technol. 2017;243(10):1681-92. doi:10.1007/s00217-017-2878-2

[122] Mehyar GF, Han JH. Active packaging for fresh-cut fruits and vegetables. In: Brody AL, Zhuang H, Han JH, editors. Modified atmosphere packaging for fresh-cut fruits and vegetables. Chichester, UK: John Wiley \& Sons; 2011, p. 267.

[123] Lee YS, Beaudry R, Kim JN, Harte BR. Development of a 1-methylcyclopropene (1-MCP) sachet release system. J Food Sci. 2006;71(1):C1-6. doi:10.1111/j.1365-2621.2006.tb12380.x

[124] Hotchkiss J, Watkins C, Sanchez D. Release of 1-methylcyclopropene from heat-pressed polymer films. J Food Sci. 2007;72(5):E330E4. doi:10.1111/j.1750-3841.2007.00391.x

[125] Wang S, Zhou Q, Zhou X, Wei B, Ji S. The effect of ethylene absorbent treatment on the softening of blueberry fruit. Food Chem. 2018;246:286-94. doi:10.1016/j.foodchem.2017.11.004

[126] Xu F, Liu S. Control of postharvest quality in blueberry fruit by combined 1-methylcyclopropene (1-MCP) and UV-C irradiation. Food Bioprocess Technol. 2017;10(9):1695-703. doi:10.1007/s11947-017-1935-y

[127] Chiabrando V, Giacalone G. Shelf-life extension of highbush blueberry using 1-methylcyclopropene stored under air and controlled atmosphere. Food Chem. 2011;126(4):1812-6. doi:10.1016/j.foodchem.2010.12.032

[128] Grozeff GEG, Alegre ML, Senn ME, Chaves AR, Simontacchi M, Bartoli CG. Combination of nitric oxide and 1-MCP on postharvest life of the blueberry (Vaccinium spp.) fruit. Postharvest Biol Technol. 2017;133:72-80. doi:10.1016/j.postharvbio.2017.06.012

[129] Jacxsens L, Devliegherre F, Van der Steen C, Siro I, Debevere J. Application of ethylene adsorbers in combination with high oxygen atmospheres for the storage of strawberries and raspberries. Acta Hortic. 2003;600:311-8. doi:10.17660/ActaHortic.2003.600.43

[130] Rahman SME, Khan I, Oh DH. Electrolyzed water as a novel sanitizer in the food industry: Current trends and future perspectives. Compr Rev Food Sci Food Saf. 2016;15(3):471-90. doi:10.1111/1541-4337.12200

[131] Ma L, Zhang M, Bhandari B, Gao Z. Recent developments in novel shelf life extension technologies of fresh-cut fruits and vegetables. Trends Food Sci Technol. 2017;64:23-38. doi:10.1111/1541-4337.12200

[132] De Corato U. Improving the shelf-life and quality of fresh and minimally-processed fruits and vegetables for a modern food industry: A comprehensive critical review from the traditional technologies into the most promising advancements. Crit Rev Food Sci Nutr. 2019:1-36. doi:10.1080/10408398.2018.1553025

[133] Crowe KM, Bushway AA, Bushway RJ. Effects of alternative postharvest treatments on the microbiological quality of lowbush blueberries. Small Fruits Rev. 2005;4(3):29-39. doi:10.1300/J301v04n03_03

[134] de Siqueira Oliveira L, Eça KS, de Aquino AC, Vasconcelos LB. Hydrogen peroxide $\left(\mathrm{H}_{2} \mathrm{O}_{2}\right)$ for postharvest fruit and vegetable disinfection. In: Siddiqui MW, editor. Postharvest disinfection of fruits and vegetables. London: Elsevier; 2018, p. 91-9.

[135] Aday MS, Caner C. The applications of active packaging and chlorine dioxide for extended shelf life of fresh strawberries. Packag Technol Sci. 2011;24(3):123-36. doi:10.1002/pts.918

[136] Chironi S, Bacarella S, Altamore L, Ingrassia M. Quality factors influencing consumer demand for small fruit by focus group and sensory test. J Food Prod Market. 2017;23(8):857-72. doi:10.1080/10454446.2017.1244791

[137] Kraśniewska K, Ścibisz I, Gniewosz M, Mitek M, Pobiega K, Cendrowski A. Effect of pullulan coating on postharvest quality and shelf-life of highbush blueberry (Vaccinium corymbosum 1.). Materials. 2017;10(8):965. doi:10.3390/ma10080965

[138] Umagiliyage AL, Becerra-Mora N, Kohli P, Fisher DJ, Choudhary R. Antimicrobial efficacy of liposomes containing D-limonene and its effect on the storage life of blueberries. Postharvest Biol Technol. 2017;128:130-7. doi:10.1016/j.postharvbio.2017.02.007

[139] Hassanpour H. Effect of Aloe vera gel coating on antioxidant capacity, antioxidant enzyme activities and decay in raspberry fruit. LWT - Food Sci Technol. 2015;60(1):495-501. doi:10.1016/j.1wt.2014.07.049

[140] Guerreiro AC, Gago CM, Faleiro ML, Miguel MG, Antunes MD. Raspberry fresh fruit quality as affected by pectin-and alginate-based edible coatings enriched with essential oils. Sci Hort. 2015;194:138-46. doi:10.1016/j.scienta.2015.08.004 
[141] Guerreiro AC, Gago CM, Miguel MG, Faleiro ML, Antunes MD. The influence of edible coatings enriched with citral and eugenol on the raspberry storage ability, nutritional and sensory quality. Food Pack Shelf Life. 2016;9:20-8. doi:10.1016/j.fpsl.2016.05.004

[142] Peano C, Briano R, Giuggioli NR, Girgenti V, Sottile F. Evolution of qualitative characteristics during blueberry fruit storage in a modified atmosphere. Acta Hortic. 2015;1071:343-8. doi:10.17660/ActaHortic.2015.1071.43

[143] Moggia C, Lobos GA, Retamales JB. Modified atmosphere packaging in blueberries: Effect of harvest time and moment of bag sealing. Acta Hortic. 2014;1017:153-8. doi:10.17660/ActaHortic.2014.1017.16

[144] Toivonen PMA, Kempler C, Escobar S, Emond J. Response of three raspberry cultivars to different modified atmosphere conditions. Acta Hortic. 1999;505:33-8. doi:10.17660/ActaHortic.1999.505.2

[145] Giuggioli NR, Briano R, Baudino C, Peano C. Effects of packaging and storage conditions on quality and volatile compounds of raspberry fruits. CyTA-J Food. 2015;13(4):512-21. doi:10.1080/19476337.2015.1011238

[146] Pangloli P, Hung Y-C. Reducing microbiological safety risk on blueberries through innovative washing technologies. Food Control. 2013;32(2):621-5. doi:10.1016/j.foodcont.2013.01.052

[147] Chen Y, Hung Y-C, Chen M, Lin H. Effects of acidic electrolyzed oxidizing water on retarding cell wall degradation and delaying softening of blueberries during postharvest storage. LWT - Food Sci Technol. 2017;84:650-7. doi:10.1016/j.lwt.2017.06.011

[148] Chen Y, Hung Y-C, Chen M, Lin M, Lin H. Enhanced storability of blueberries by acidic electrolyzed oxidizing water application may be mediated by regulating ROS metabolism. Food Chem. 2019;270:229-35. doi:10.1016/j.foodchem.2018.07.095

[149] Zheng Y, Yang Z, Chen X. Effect of high oxygen atmospheres on fruit decay and quality in chinese bayberries, strawberries and blueberries. Food Control. 2008;19(5):470-4. doi:10.1016/j.foodcont.2007.05.011

[150] Jiang A, Meng X, Hu W, Tian M, Wang Y. Effects of high $\mathrm{CO}_{2}$ shock treatment on physiological metabolism and quality of postharvest blueberry fruits. Trans Chinese Soc Agric Eng. 2011;27(3):362-8. 